\title{
Belediyelerin İlan ve Reklam Vergisi Uygulamaları Üzerine Bir Değerlendirme
}

\section{An Evaluation of the Announcement and Advertisement Tax Practices of the Municipalities}

\author{
Ahmet Alptekin Duru a,* \\ ${ }^{a}$ Dr. Öğr. Üyesi, Akdeniz Üniversitesi, İktisadi ve İdari Bilimler Fakültesi, Siyaset Bilimi ve Kamu Yönetimi Bölümü, Antalya/Türkiye. \\ ORCID:0000-0002-2969-6406
}

\section{MAKALE BİLGİSİ}

Makale Geçmişi:

Başvuru tarihi: 11 Ekim 2019

Düzeltme tarihi: 17 Ocak 2020

Kabul tarihi: 12 Şubat 2020

\section{Anahtar Kelimeler:}

İlan ve Reklam Vergisi

Tabela

Vergi tarifesi

Belediye

Büyükşehir belediyesi

\section{ARTICLE INFO}

\section{Article history:}

Received 11 October 2019

Received in revised form 17 January 2020

Accepted 12 February 2020

Keywords:
Announcement and Advertisement Tax
Signboard
Tax tariff
Municipality
Metropolitan municipality

ÖZ

İlan ve Reklam Vergisi'nin bir belediye geliri olmanın yanı sıra kentte tabela yoğunluğunu azaltmak gibi mali olmayan bir amacı da vardır. İlan ve Reklam Vergisi'nin bu iki işlevini, konusunu, kapsamını ve tarifesini, belediye gelirleri içindeki yerini, tahsil etme yetkisi açısından büyükşehir belediyeleri ve büyükşehir ilçe belediyeleri arasındaki durumunu inceleyen müstakil bir çalışmaya literatürde rastlanmamıştır. Sayılan bu hususlar mevzuat taraması, mahkeme kararları ve belediyelerin bütçe gerçekleșme sayıları üzerinden bu makalede incelenerek uygulamada karşılaşılan sorunlar tespit edilmeye çalışılmıştır. Sonuç olarak makalede kanundaki tarifelerin ve vergiyi doğuran olayların güncellenmesi, belediyelere tarife belirleme yetkisi verilmesi ve büyükşehirlerde bu vergiyi toplama yetkisinin tamamen ilçe belediyelerine bırakılması önerilmektedir.

\section{Giriş}

1924 yılında çıkarılan 423 sayılı Belediye Vergi ve Resimleri Kanunu'nun 14. maddesiyle ticari ve sinai

\section{A B S T R AC T}

Announcement and Advertisement Tax is a municipal revenue but also it has an extra-fiscal purpose which is decreasing the density of signboards in the city. There has been not a separate article in the literature analyzing the dual functions, the subject, the coverage and tariff, the share in the municipal revenue, the division of collection authority between the district municipality and the metropolitan municipality in the metropolitan area of the Announcement and Advertisement Tax. These issues are analyzed via review of the regulations, court orders and budget realizations of the municipalities. Therefore, the problems arising in practice are determined. Consequently, several suggestions developed such as tariffs and taxable events should be updated, municipalities should have the power to determine the tariff, and the district municipality should be the collection authority in the metropolitan area.

\footnotetext{
${ }^{1}$ Vergi, resim ve harç kavramlarının tarihsel gelişimi için bkz. Yılmaz (2018).

${ }^{2}$ 6.3.1924 tarihli ve 63 sayılı Resmi Gazete'de yayımlanan 423 sayılı Belediye Vergi ve Resimleri Kanunu'nun 14. maddesinin metni şu şekildedir (TBMM, 2019): "Bilûmum dükkânlarla ticari ve sinai müessesatın kapılarına sahiplerinin isimlerini ve müessesenin iştigalâtın
}

tesislere tabela asma zorunluluğu getirilmiş ve bu tabelalar ile el ve duvar ilanlarından belediye meclisince belirlenecek tarifeye göre her yıl 'resim'1 alınacağı düzenlenmiştir. ${ }^{2}$ İlan ve Reklam Resmi, 1948 yılında yürürlüğe giren 5237 sayılı

gösterir Türkçe bir levha asmak mecburidir. Bu levhalarda şayet Türkçenin gayri lisan ve yazlla ile dahi yazllmak istenilirse yazllacak yazıların gerek hacmi, gerek puntu Türkçenin nisfi derecesini tecavüz edemez ve Türkçenin altına yazllır. Bu suretle talik edilen levhalardan beledive meclislerince tanzim olunacak tarifeye göre senevi bir resim alınır. Levhalarda Türkçeden gayri lisan ve yazı ile olan kısımların beherinden ayrıca ikişer kat resim

\footnotetext{
* Sorumlu yazar/Corresponding author

e-posta: ahmetduru@akdeniz.edu.tr
} 
Belediye Gelirleri Kanunu'nda da düzenlenen bir belediye geliri olmuştur. ${ }^{3}$ İlan ve Reklam Vergisi tabiri ise ilk olarak 1981 yılında çıkarılan 2464 sayılı Belediye Gelirleri Kanunu'nda kullanılmıştır.

Literatürde belediye gelirleri, yerel vergi yönetimi, belediyelerin mali özerkliği gibi çalışmalarda İlan ve Reklam Vergisi'ne ilişkin değerlendirmeler bulunmakla birlikte bu makaledeki kapsamıla münhasıran İlan ve Reklam Vergisini inceleyen bir çalışmaya tarafimızca rastlanmamıştır. ${ }^{4} \mathrm{Bu}$ açıdan makale, belediyenin bu gelir kalemini tarihsel süreci, mahkeme kararları, mevzuat değişiklikleri, tahsil edilen gelirleri ve uygulamada karşılaşılan sorunları çerçevesinde inceleyerek literatüre katkı sunmayı amaçlamaktadır.

İlan ve Reklam Vergisi'nin birisi kişilerin ilan ve reklam maliyetini artırarak kentin tabela yoğunluğunu azaltmak ve diğeri de belediyeye gelir sağlamak şeklinde iki temel işlevi vardır. Tabela yoğunluğunu azaltmak işlevi 2464 sayılı Belediye Gelirleri Kanunu'nun gerekçesinde yer almamıştır fakat pratikte vergiden kaçınmak için kişilerin ilan ve reklamlarını mümkün olduğunca azaltmak yönündeki tavrı bu sonuca yol açmaktadır. Bu makalede, İlan ve Reklam Vergisi'nin konusu, kapsamı, tarifesi, belediye gelirleri içindeki yeri ile büyükşehir belediyeleri ve büyükşehir ilçe belediyeleri arasındaki yetki paylaşımı belediyelerin uygulamaları ve mahkeme kararları çerçevesinde incelenecek ve değerlendirilecektir.

\section{2. İlan ve Reklam Vergisi'nin Konusu ve Kapsamı}

İlan ve Reklam Vergisi, 2464 sayılı Belediye Gelirleri Kanunu'nun 12 ilâ 16. maddelerinde düzenlenmiştir. İlan ve Reklam Vergisi, belediye sınırları ile mücavir alanları ${ }^{5}$ içinde yapılan her türlü ilan ve reklam üzerinden alınacağı belirtilen bir belediye gelir kalemidir. Kanunda verginin konusu olan ilan ve reklam ibarelerinin tanımı yapılmamıştır ${ }^{6}$ fakat tarife cetvelinde açıklamalar ve örnekler verilerek kapsamı gösterilmiştir. Bu vergiyi yetki sınırları içinde il belediyeleri, ilçe belediyeleri, belde belediyeleri, büyükşehir belediyeleri veya büyükşehir ilçe belediyeleri tahsil edebilir.

Türk vergi hukukunda esas yöntem verginin asıl mükelleften tahsil edilmesi olmakla birlikte vergi alacağını güvence altına almak, vergiyi en az masrafla ve kolay bir biçimde tahsil etmek ve vergilemeyle ilgili usulün tam olarak yerine getirilmesini sağlamak için 'vergi sorumlusu' olarak nitelendirilen üçüncü kişilere de çeşitli sorumluluklar yüklenmiştir (Gerçek, 2005: 189). 2464 sayılı Belediye Gelirleri Kanunu'nun 13. maddesinin ikinci fikrası uyarınca

alınır. El ve divar [duvar] ilânlariyle diğer her nevi ilânattan belediye meclislerince tanzim olunacak tarifeye göre resim alınır."

3 9.7.1948 tarihli ve 6953 sayılı Resmi Gazete'de yayımlanan 5237 sayılı Belediye Gelirleri Kanunu'nun 21. maddesinde İlan ve Reklam Resmi düzenlenmiştir. 423 sayılı Kanun'da olduğu gibi levha asma ve levhaların Türkçe olma zorunluluğu, Türkçe'nin dışındaki dillerde yazılan yazıların Türkçe'nin altına yazılması ve Türkçe yazıdan daha küçük olma zorunluluğu, levhalar ile diğer ilan ve reklamlardan belediye meclisince belirlenecek tarifeye göre resim alınacağı kanunda yer almıștır. 5237 sayılı Kanun'da ayrıca levhaların şekil ve ebatlarının belediyelerce tespit edileceğ düzenlenmiştir.

${ }^{4}$ Doğrusöz (1982) ve Bayer (2019) konuyu vergiyi doğuran olay, tarh, tahakkuk, istisnalar gibi sadece vergisel boyutuyla incelemiştir.

55393 sayılı Belediye Kanunu'nun 6. maddesi uyarınca belediye sınırları, belediye meclisinin kararı ve kaymakamın görüşü üzerine valinin onayı ile
"Ilan ve reklam işlerini mutat meslek olarak ifa edenler, başkaları adına yaptıkları ilan ve reklamlara ait vergileri mükellefler adına ilgili belediyeye yatırmaktan sorumludurlar." Böylelikle belediyelerin İlan ve Reklam Vergisi gelirlerini vergi sorumlusu vasitasıyla daha az masraf yapılarak ve daha kolay biçimde tahsili amaçlanmıştır.

2464 say1l Belediye Gelirleri Kanunu'nun 16. maddesine göre "Vergiye tabi ilan ve reklamlarda, ilan ve reklam işinin mükellefçe yapılması halinde ilan veya reklam işinin yapilmasindan önce mükellef tarafindan, ilan ve reklam işinin bu işi mutad meslek olarak ifa edenler tarafindan yapılması halinde ilan ve reklam işini yapanlarca ilan veya reklamın yapıldı $\breve{g}$ ayı takip eden ayın 20 nci günü akşamına kadar verilecek beyanname üzerine, tarh ve tahakkuk ettirilir." Madde metninde görüldüğü üzere mükelleflerin beyanname dışında bir belge sunması gerekli değildir. Maliye Bakanlığı'nın yayımladığı Belediye Gelirleri Kanunu Genel Tebliği (Seri No: 41) ${ }^{7}$ ile belediyelerce mükelleflerin beyanlarının esas alınması ve bunun dışında bir belge (kimlik fotokopisi, kira kontratı, vergi dairelerince düzenlenen yoklama fişi, vergi levhası, ticaret sicil gazetesi vb.) talep edilmemesi gerektiği vurgulanmıştır. Tebliğ'e göre belediyeler ihtiyaç duymaları halinde beyannamenin kontrolü amaciyla yerinde yoklama ve tespit yapacaktır.

2464 sayılı Belediye Gelirleri Kanunu'nun 12. maddesinde verginin konusu "belediye sinırlart ve mücavir alanlar içinde yapllan her türlü ilan ve reklam" olarak belirlenmiştir. Buna rağmen 15. maddede yer alan vergiyi doğuran olaylar (levha asılması, broşür dağıtılması, afiş yapıştırılması vb.) 1981 yılından beri güncellenmemiş, sadece bir defa 2004 yılında vergi tarifeleri değiştirilmiştir. Diğer taraftan güncel reklam uygulamalarının vergilendirilmek istenmesi halinde, kanundaki vergiyi doğuran olayların güncel olmaması sonucu belediyeler arasında farklı uygulamalar doğmakta ve mükellefler itiraz edebilmektedir; örneğin günümüzde kullanılan led ekran, totem ve lazerle yapılan geçici mahiyetteki reklamlara hangi tarifenin uygulanacağı belirsizdir (Marmara Belediyeler Birliği, 2015: 5). 11. Kalkınma Planı Yerel Yönetimler ve Hizmet Kalitesi Özel İhtisas Komisyonu Raporu'nda (ÖİK, 2019: 135) kanun değişikliği ile ilan ve reklam vergisine ilişkin tarifelerin günümüzdeki reklam unsurlarını kapsayacak şekilde bir yıl içinde revize edilmesi öngörülmüştür.

Özel radyo ve televizyonlarda yapılan reklamların İlan ve Reklam Vergisi kapsamına alınması da önerilmektedir (Şener, 1998: 19). İlk bakışta verginin konusu her türlü ilan ve reklam olarak belirlendiği için mümkün görünmekle

kesinleşir. Mücavir alan, büyükşehir olmayan illerde, belediyenin hizmet sunduğu fakat belediyenin sınırları içinde olmayıp belediye sınırları civarındaki yerlerdir. 12.11.2012 tarihli ve 6360 sayılı Kanun'un 6 . maddesiyle 5216 sayılı Büyükşehir Belediyesi Kanunu'nun 5. maddesi değiştirilmiş, büyükşehir belediyelerinin sınırları il mülki sınırları ve büyükşehir ilçe belediyelerinin sınırları bu ilçelerin mülki sınırları olmuştur. Dolayısıyla büyükșehir olan illerde mücavir alan kalmamış, bütün mülki sınırlar büyükşehir belediyesi ile büyükşehir ilçe belediyelerinin yetki alanına dâhil edilmiştir.

6 Bayer (2019: 64) tarafından ilan ve reklam ibarelerinin tanımının yapılmamasının verginin kanuniliği ilkesine aykırılık oluşturduğu iddia edilmektedir.

${ }^{7}$ 28.2.2012 tarihli ve 28218 sayılı Resmi Gazete'de yayımlanmıştır. 
birlikte vergiyi doğuran olaylar arasında yayım suretiyle yapılan reklamlardan bahsedilmemesi, radyo ve televizyon kanalıyla yapılan reklamların vergilendirilmesine engeldir. Ayrıca kanun koyucunun iradesi de bu yönde oluşmuştur. 2464 sayılı Kanun'un Maliye Bakanlığ tarafindan hazırlanan ilk taslağında İlan ve Reklam Vergisi'nin hem maktu hem de nisbi şekilde tahsil edilmesi önerilmiş fakat Milli Güvenlik Konseyi İhtisas Komisyonu nisbi tarifeyi taslaktan çıkarmıştır. ${ }^{8}$ Komisyon ayrıca yayım vasıtalarıyla (gazete, dergi, broşür, kitap, albüm, takvim vb.) yapılan ilan ve reklamlar, sinema, tiyatro, hipodrom, stadyum gibi yerlere sesle ve görüntüyle yapılan ilanlar ile belediye hoparlör ve tellallarıyla yapılan ilan ve reklamlar için, alınan ücret üzerinden nisbi tarifeye tabi olan vergiyi doğuran olayları taslak metninden çıkarmıştır (Gelir İdaresi Başkanlığı, 2019b). Dolayısıyla kanun koyucunun iradesinin yayım vasıtasıyla yapılan reklamlardan vergi alınmaması yönünde olduğu düşünülebilir.

Öte yandan, internet üzerinden yapılan ilan ve reklamların da İlan ve Reklam Vergisi'ne tabi olması gerektiği fakat bunlara uygulanacak tarifenin belli olmadığı da öne sürülmektedir (Ortaç ve Akçay, 2015: 56). 2019 yılından itibaren internet ortamında verilen reklam hizmetleri veya internet ortamında reklam hizmeti verilmesine aracılık edilmesi 476 sayılı Cumhurbaşkanı Kararı $^{9}$ ile gelir ve kurumlar vergisi tevkifatı kapsamına alınmıştır (Coşkun Karadağ, 2019: 83). Fakat internet reklamlarından İlan ve Reklam Vergisi alınması konusuna ilişkin bir tarife henüz düzenlenmediği için, Anayasa'nın 73. maddesinin üçüncü fikrasındaki 'verginin kanuniliği ilkesi' uyarınca belediyelerin internet ortamındaki reklamlardan vergi alması mümkün değildir.

\section{3. İlan ve Reklam Vergisi’nin Tabela Yoğunluğunu Azaltmak İşlevi}

Vergileme yoluyla piyasanın yol açtığı olumsuzlukların siyaseten tercih edilecek biçimde giderilmesi ilk olarak Pigou (1920) tarafindan önerilmiştir (Barnett ve Yandle, 2005: 218). 'Yönlendirici vergilendirme' olarak tabir edilen verginin mali amaçlı olmayacak şekilde kullanımı, vergiyi doğuran olayın gerçekleşmesini kontrol etmenin aracı olarak bireylerin davranışlarını özendirmekte veya caydırmaktadır (Göker, 2011: 12). Bu çerçevede İlan ve Reklam Vergisi'nin ilk işlevi vergilendirme yoluyla bireyleri caydırarak şehirdeki tabela yoğunluğunu azaltmaktır. Tabela yoğunluğunu azaltmak için Türkiye'de belediyelerin başlıca iki aracı vardır, ilki vergi tarifesini kişilerin tabela talebini düşürecek şekilde yükseltmek ve ikincisi de tabelalar için standartlar getirmektir.

Devletler zaman zaman olumsuz dişsallıkları gidermek veya azaltmak için belirli mal ve hizmetlerin talebini düşürecek şekilde vergi ihdası yoluna gidebilir. Vergi yoluyla kişilerin davranışlarını değiştirmek amacı güdülmesi halinde kişilerin talebinin esnekliği önemli bir unsur olur. İlan ve reklam

8 Milli Güvenlik Konseyi İhtisas Komisyonu'nun 7.5.1981 tarihli ve E.1/105, K. 41 sayılı Raporu (Gelir İdaresi Başkanlığı, 2019a).

${ }^{9} 19.12 .2018$ tarihli ve 30630 sayılı Resmi Gazete'de yayımlanmıştır.

10 Örneğin Türkiye'de alkollü içecekler ve tütün ürünleri üzerinde uygulanan özel tüketim vergisinin tüketimi azaltma amacında beklenileni tam olarak veremediği, tüketici tercihlerine yön vermede başarılı olamadığ ve tüketicileri kaçak ürünleri kullanmaya sevk ettiği tespit edilmiştir (Hayrullahoğlu, 2015: 107-108; Çetin ve Özkan, 2018: 284-285). Amerika Birleşik Devletleri'ndeki akaryakıt vergisi ve OECD ülkelerindeki çevre bağlamında, 'Şayet tabelalar için vergi ödemeyecek olsa idi kişiler daha büyük tabela asmayı tercih eder miydi?' sorusunun cevabı İlan ve Reklam Vergisi'nin tabela yoğunluğunu azaltmak işlevinin etkinliğini ortaya koyar. ${ }^{10}$ Öte yandan, her bir belediyenin yetki alanında kişilerin tabela asmaya yönelik talebi bilinmez. Bu sebeple, tabela kirliliğini önleyecek vergi tarifesi düzeyini belediyelerin yerel koşulları dikkate alarak belirlemesi ve talepteki değişkenliğe göre güncelleştirmesi gerekir. Fakat 2013 yılından itibaren belediye meclislerinin tarife belirleme yetkisinin bulunmaması, İlan ve Reklam Vergisi'nin tabela yoğunluğunu azaltmak işlevini kısıtlamaktadır.

Bununla birlikte belediyelerin tabelalar için standart getirmenin yanı sira bu standartlara uymayanları da engellemesi gerekir. Fakat belediyeler tarafindan ihdas edilen standartlar merkezi kentsel alanlarda uygulanabilse bile, belediye sınırlarının tamamında standartlara aykırı davrananlara yaptırım uygulanması kolay değildir.

İlan ve Reklam Resmi'ni düzenleyen 1924 yılında çıkarılan 423 sayılı Belediye Vergi ve Resimleri Kanunu'nun 14. maddesinde tabelaların fiziksel özellikleri konusunda bir düzenleme yoktur. Fakat tabelalarda kullanılacak lisanın Türkçe olması zorunlu tutulmuştur. Türkçe dışında bir dilin de tabelada yazılacak olması halinde Türkçe yazının yarısından daha büyük olmamak üzere altına yazılması emredilmiştir. Ayrıca Türkçe dışındaki kısımlardan iki misli resim alınması öngörülmüştür. Diğer taraftan 1930 tarihli 1580 sayılı Belediye Kanunu'nun 19. maddesi uyarınca belediye belde halkının yararı için emir ve yasak koyma yetkisine sahiptir. Bu hükme istinaden belediyeler tabelaları düzenlemek için kararlar alabilmiştir.

1948 yılında yürürlüğe giren 5237 sayılı Belediye Gelirleri Kanunu'nun 'İlan ve reklam resmi' başlıkl1 21. maddesinde Türkçe tabela hassasiyeti aynı derecede gözetilmiştir. Buna ilave olarak tabelaların renk, şekil, genişlik ve asılış hususlarını belediyelerin düzenleyebileceği belirtilmiştir. 1981 tarihli 2464 sayılı Belediye Gelirleri Kanunu'nda tabelaların Türkçe olma zorunluluğu kaldırılmışș ${ }^{11}$, yabancı dildeki tabelaları caydıracak şekilde iki misli tarife uygulamasından vazgeçilmiştir.

5393 sayılı Belediye Kanunu'nun 15. maddesinin birinci fikrasinın (n) bendinde "Reklam panolarl ve tanitıcı tabelalar konusunda standartlar getirmek" belediyelerin yetkileri arasında sayılmıştır. 5216 sayılı Büyükşsehir Belediyesi Kanunu'nun 7. maddesinin birinci fikrasının (g) bendine göre de "ilân ve reklam asılacak yerleri ve bunların şekil ve ebadını belirlemek” büyükşehir belediyelerinin yetkisi dâhilindedir. Binaenaleyh büyükşehir sınırlarında varsa öncelikle büyükşehir belediyesinin il genelini kapsayan düzenlemeleri esas alınacak, bunlara aykırı olmamak üzere ilçe belediyeleri de tabelalar konusunda düzenleme yapabilecektir. Görüldüğü üzere ilan ve reklam tabelalarına getirilecek standartlar konusunda büyükşehir

vergileri üzerine yaptıkları çalışmada Barnett ve Yandle (2005: 234) da bütçe geliri saikinin piyasayı düzenleme saikinden daha güçlü olduğunu belirtmiştir.

11 Hâlâ yürürlükte olan 10.4.1926 tarihli ve 805 sayılı İktisadi Müesseselerde Mecburi Türkçe Kullanılması Hakkında Kanun, Türk șirketlerinin Türkiye dâhilindeki her türlü ișlem, sözleșme, haberleșme, hesap ve defterlerinin Türkçe tutulmasını emretmektedir. Fakat bu Kanun'da tabelalara ilişkin bir hüküm yoktur. 
belediyesi ile ilçe belediyeleri arasında bir vesayet ilișkisi kurulmuştur. ${ }^{12}$ Fakat bu vesayet ilişkisi, Gözler'in (2018) iddiasına göre anayasal temeli olan 'mahalli idareler arasında vesayet ilişkisi olmaz' ilkesine aykırılık teşkil etmektedir. Anayasa'nın 127. maddesine göre sadece merkezi idare ile mahalli idareler arasında bir vesayet ilişkisi kurulabilir, mahalli idarelerin özerkliği bunları merkezi idareye karşı sınırlı bir şekilde korurken diğer mahalli idarelere karşı mutlak bir şekilde korur. Bu sebeple büyükșehir belediyesi ilçe belediyesi üzerinde bir vesayet yetkisine sahip olamaz (Gözler, 2018: 246-247). ${ }^{13}$

Belediyelerin tabela yoğunluğunu önlemek için kullanabileceği bir araç da Türk Standartları Enstitüsü'nün tabela zemin ve yazı renkleri, dili, ebatları ve asılmas1 gibi konular düzenleyen TS 13813 sayılı Kurum ve Kuruluşlarda Kullanılan Tabelalar İçin Kurallar standardıdır. Bu standart mecburi olmadığı halde belediyeler tarafindan bir yönetmelik çıkarılarak kullanılması sağlanabilir, fakat 2018 yılında yürürlüğe konulduğu için belediyeler tarafindan henüz yönetmeliklerine dercedilmemiştir ve uygulama düzeyi düşüktür.

5216 sayılı Büyükşehir Belediyesi Kanunu'nun 23. maddesinin birinci maddesinin (e) bendinde "7 nci maddenin birinci fikrasinin ( $g$ ) bendinde belirtilen alanlar [mahalleleri ilçe merkezine bağlayan yollar, meydan, bulvar, cadde ve ana yollar] ile bu alanlara cephesi bulunan binalar üzerindeki her türlü ilân ve reklamların vergileri ile asma, tahsis ve bakım ücretleri" büyükșehir belediyesinin gelirleri arasında sayılmıştır. 2464 sayılı Belediye Gelirleri Kanunu'nun 97. maddesinde ise belediyelerin harç veya katılma payı konusu yapılmayan ve ilgililerin isteğine bağlı olarak ifa edecekleri hizmetler karşıllı̆ında ücret almaları düzenlenmiştir.

Maliye Bakanlığı'nın yayımladığı Belediye Gelirleri Kanunu Genel Tebliği (Seri No: 31$)^{14}$ ile belediyelerin İlan ve Reklam Vergisi dışında verecekleri asma, tahsis ve bakım hizmeti karşılığında ücret alabileceği ifade edilmektedir. Tebliğ'e göre tabela asma, tahsis ve bakım hizmeti ücretlerinin alınabilmesi için belediyelerin meclislerinde bu işler için tarife belirlemesi, kișilerin ilan ve reklamlarını asabilmek için belediyelerden asma, tahsis ve bakım hizmeti talebinde bulunmas1, belediyelerin de bu hizmeti yerine getirmesi gereklidir. Asma, tahsis ve bakım hizmeti talep

\footnotetext{
125216 sayılı Kanun'un 27. maddesinin birinci fikrası da tabelalara getirilecek standartlar konusunda büyükşehir belediyesi ile ilçe belediyeleri arasındaki vesayet ilișkisini pekiștirmektedir. Buna göre "Büyükșehir kapsamindaki belediyeler arasinda hizmetlerin yerine getirilmesi bakımından uyum ve koordinasyon, büyükssehir beledivesi tarafindan sağlanır. Büyükșehir belediyesi ile ilçe belediyeleri veya ilçe belediyelerinin kendi aralarında hizmetlerin yürütülmesiyle ilgili ihtilaf çıkmas durumunda, büyükșehir belediye meclisi yönlendirici ve düzenleyici kararlar almaya yetkilidir."

${ }^{13}$ Gözler (2018: 253-255) bu hukuksal problemin Anayasa'da bir değişiklik yapılarak mahalli idareler arasında vesayet ilişkisi kurulmasına izin verilmesi yahut büyükșehir belediyelerinin tüzel kişiliklerinin kaldırılması yoluyla çözülebileceğini kaydetmektedir.

${ }^{14}$ 16.5.2005 tarihli ve 25817 sayılı Resmi Gazete'de yayımlanmıştır.

15 Gündüzöz (2016: 63) büyükșehir belediyesinin meydan, cadde, bulvar, park vb. alanlardaki ilan ve reklam panolarında tasarruf yetkisinin büyükșehir belediyesinde, bu alanlar dıșında ise tasarruf yetkisinin ilçe belediyesinde olduğu şeklinde İçișleri Bakanlığı Hukuk Müşavirliği'nin görüş tesis ettiğini kaydetmektedir.

${ }^{16}$ Bendin metni şu şekildedir: "[Büyükșehir belediyesinin görev, yetki ve sorumlulukları şunlardır:]Büyükşehir ulaşım ana plânını yapmak veya
}

edilmeyen ilan ve reklamları için, İlan ve Reklam Vergisi dışında belediyelerce herhangi bir ücret alınamaz.

Görüldüğü üzere belediyelerin tabela asma, tahsis ve bakım hizmeti kişilerin isteğine bağlı bir hizmettir. Özellikle belediyelerin tabelalar hakkında standart getirmesi halinde, tabela kirliliğini önlemek konusunda asma ve bakım hizmeti faydalı bir araç olarak kullanılabilir.

Belediyeler tarafından konulan veya izin verilen açık hava reklam materyalleri (bilbord, raket, megalayt, pano, led ekran vb.) belediyeler açısından bir gelir kaynağı olarak görülmekte, belediyelerce işletilmekte veya 2886 sayılı Devlet İhale Kanunu'na göre ihale edilmek suretiyle işlettirilmektedir. ${ }^{15}$ Açık hava reklam materyalleri hangi belediyenin yetki alanında ise o belediye tarafindan İlan ve Reklam Vergisi alınmak durumundadır. Fakat büyükşehir belediyesi tarafından hizmet verilen kara, deniz, su ve demiryolu üzerinde işletilen (minibüs, otobüs, tramvay, metro vb. durakları) toplu taşıma hizmetlerine ilişkin yerlerdeki açık hava reklam materyallerinden hangi belediyenin İlan ve Reklam Vergisi alacağ tartışılacağı üzere- mevzuatta açık değildir. Zira bu yerler 5216 sayılı Büyükşehir Belediyesi Kanunu'nun 7. maddesinin birinci fikrasının (f) bendi ${ }^{16}$ uyarınca büyükşehir belediyelerinin yetki alanındadır. Diğer taraftan buralardan alınacak İlan ve Reklam Vergisi büyükșehir belediyesi gelirleri arasında sayılmamıştır. Pratikte ise toplu taşıma duraklarındaki reklam işleri sebebiyle büyükşsehir belediyelerinin İlan ve Reklam Vergisi tahsil ettiği görülmektedir. ${ }^{17}$

\section{Büyükşehirlerde İlan ve Reklam Vergisi'ni Tahsile Yetkili Belediye}

31.3.2014 tarihindeki Mahalli İdareler Genel Seçimi’nin ardından 6360 sayılı Kanun'un 6. maddesi yürürlüğe girmiştir ve büyükşehir belediyesinin yetki sınırlarını belirleyen 5216 sayılı Büyükşehir Belediyesi Kanunu'nun 5. maddesi değiştirilmiştir. Böylece büyükşsehir belediyesi olan 30 ilde $^{18}$ büyükşehir belediyelerinin sınırları il mülki sınırları ve büyükşehir ilçe belediyelerinin sınırları bu ilçelerin mülki sınırları olmuştur. Büyükşehir belediyeleri ve büyükşehir ilçe belediyeleri artık sadece kentsel alanlarda değil aynı zamanda kırsal alanlarda da hizmet sunmaya başlamıştır. Belediye sınırlarının genişlemesiyle birlikte daha önce belediye sınırı kapsamında olmayan bazı yerlerde hangi

yaptırmak ve uygulamak; ulaşım ve toplu taşıma hizmetlerini plânlamak ve koordinasyonu sağlamak; kara, deniz, su ve demiryolu üzerinde işletilen her türlü servis ve toplu taşıma araçları ile taksi sayllarını, bilet ücret ve tarifelerini, zaman ve güzergâhlarını belirlemek; durak yerleri ile karayolu, yol, cadde, sokak, meydan ve benzeri yerler üzerinde araç park yerlerini tespit etmek ve isletmek, ișlettirmek veya kiraya vermek; kanunlarin belediyelere verdiği trafik düzenlemesinin gerektirdiği bütün işleri yürütmek."

${ }^{17}$ Örneğin Antalya Büyükșehir Belediyesi İlan ve Reklam Yönetmeliği’nin 7. maddesinde bu gibi yerler büyükşehir belediyesi yetki alanında sayılmıştır.

182004 yılında yürürlüğe giren 5216 sayılı Büyükşehir Belediyesi Kanunu'nun geçici 2. maddesiyle, İstanbul ve Kocaeli illerinde büyükșehir belediyesi sınırları il mülkî sınırı olmuştur. Fakat 6360 sayılı Kanun'a kadar bu illerdeki ilçe belediye sınırları ilçe mülki sınırına erişmemiştir, ayrıca İstanbul ve Kocaeli'nde bulunan il özel idareleri ve köyler tüzel kișiliklerini korumuştur. 6360 sayılı Kanun'un 1. maddesinin dördüncü ve beşinci fikralarıyla İstanbul ve Kocaeli illerindeki il özel idaresi ve köy tüzel kişilikleri kaldırılmıştır. 
belediye tarafından İlan ve Reklam Vergisi tahsil edileceği tartışmalı duruma gelmiştir.

5393 sayılı Belediye Kanunu'nda İlan ve Reklam Vergisi'ne yönelik özel bir hüküm yoktur. Anılan Kanun'un 59. maddesinin birinci fikrasının (a) bendinde "Kanunlarla gösterilen belediye vergi, resim, harç ve katılma paylarl" belediye gelirleri arasinda sayılmak suretiyle konu düzenlenmiştir.

5216 sayılı Büyükşehir Belediyesi Kanunu'nun 23. maddesinin birinci fikrasinın (e) bendinde "7 nci maddenin birinci fikrasinin $(g)$ bendinde belirtilen alanlar [mahalleleri ilçe merkezine bağlayan yollar, meydan, bulvar, cadde ve ana yollar] ile bu alanlara cephesi bulunan binalar üzerindeki her türlü ilân ve reklamların vergileri ile asma, tahsis ve bakım ücretleri" büyükşehir belediyelerinin gelirleri arasında sayılmıştır. ${ }^{19}$ Bu hüküm aynı zamanda İlan ve Reklam Vergisi'ni tahsil edecek idareyi de düzenlemektedir. ${ }^{20}$ Başka bir deyişle, ilçe belediyeleri genel yetkili belediye olacak; büyükşehir belediyesi il mülki sınırları içinde sadece mahalleleri (6360 sayılı Kanun'la tüzel kişiliği kaldırılarak mahalleye dönüşen köyleri) ilçe merkezine bağlayan yollar, büyükşehir belediye meclisi kararıyla $^{21}$ büyükşehir belediyesi yetkisi içine alınan meydan, bulvar, cadde ve ana yollar ile bu meydanlar ve yollara cephesi $^{22}$ bulunan binalar üzerindeki ilan ve reklamlardan vergi alabilecektir. Bu tanıma göre, bir binanın şayet büyükşehir belediyesi yetkisindeki yola veya meydana cephesi varsa, binanın bütün cephelerinde doğacak İlan ve Reklam Vergisi'nin büyükşehir belediyesi tarafından alınması gerektiği şeklinde yorumlanabilir. Oysa pratikte büyükşehir belediyeleri sadece binanın kendi yetki alanındaki cepheleri üzerinden vergilendirme yapmaktadır. Danıștay'ın bir kararında ${ }^{23}$ da "ana arterde olsa bile yol kenarındaki binaların ana caddeye cephesi olmayan yüzlerine, özel mülke konu bahçe, arsa veya araziye dikilen direklere ya da panolara konulan reklamların vergileri ise ilçe veya ilk kademe belediyelerince alınacaktır" şeklinde bir yorum yapılmıştır. Böylece bir işletmenin, birisi büyükşehir belediyesi sorumluluğundaki yola ve birisi de ilçe belediyesi sorumluluğundaki yola bakan iki farklı cephesinde tabelaları varsa, iki farklı belediyeye İlan ve Reklam Vergisi ödeyebilmektedir.

Bir hizmetin bir belediyenin görevleri arasında olması o hizmetin sunulduğu mekânlardaki ilan ve reklamlardan doğacak İlan ve Reklam Vergisi'nin o belediye tarafindan tahsilini gerektirmez. Zira vergiler belli kamu hizmetlerinin karşılığ

\footnotetext{
19 Benzer bir düzenleme 27.6.1984 tarihli ve 3030 sayılı Büyük Şehir Belediyelerinin Yönetimi Hakkında Kanun Hükmünde Kararnamenin Değiştirilerek Kabulü Hakkında Kanun'un büyükşehir belediyelerinin gelirlerini belirleyen 18. maddesinin birinci fikrasının (e) bendinde şu şekilde yer almıştır: "6 ncı maddenin (A) fikrasının (c) bendinde belirtilen alanlardaki [büyükşehir dâhilindeki meydan, bulvar, cadde ve anayollar] ilan asma yerleri, elektrik direkleri, büfeler ile tercihli yollardaki bariyerlere konulacak her türlü ilan ve reklamların vergileri ile asma, tahsis ve bakım ücretleri".

205216 sayılı Büyükşehir Belediyesi Kanunu'nun 23. maddesinde "Büyükssehir beledivesine bırakılan sosyal ve kültürel tesisler, spor, eğlence ve dinlenme yerleri ile yeşil sahalar içinde tahsil edilecek her türlü belediye vergi, resim ve harçlar" büyükşehir belediyesinin gelirleri arasında sayılmıştır. Dolayısıyla bu tip yerlerde de İlan ve Reklam Vergisi büyükşehir belediyesi tarafından tahsil edilecektir.

${ }^{21} 5216$ sayılı Büyükșehir Belediyesi Kanunu'nun 27. maddesinin ikinci fikrasında yer alan "büyükşehir belediyelerinde meydan, bulvar, cadde, yol,
}

alınır. Örneğin 5216 sayılı Büyükșehir Belediye Kanunu'nun 3. fikrasının (b) bendine göre "katı atıklart toplamak ve aktarma istasyonuna taşımak" ilçe belediyelerinin görevidir. Danıştay kararında ${ }^{24}$ belirtildiği gibi büyükşehir belediyesinin yetkisine alınan bir yolda ilçe belediyesi tarafindan konulan bir katı atık konteyneri üzerindeki reklama ilişkin verginin büyükşehir belediyesi tarafindan alınması gerekir.

Büyükşehir belediyesinin İlan ve Reklam Vergisi tahsil edebileceği yerler tadadi olarak sayıldığ büyükşehirlerde İlan ve Reklam Vergisi tahsile ilişkin genel yetki ilçe belediyelerine aittir. Bir bina, tesis, taşınır veya taşınmazın büyükşehir belediyesinin yetkisinde olması, büyükşehir belediyesince işletilmesi veya ruhsatlandırılması buralardaki İlan ve Reklam Vergisinin büyükşehir belediyesi tarafından tahsilini gerektirmez. Örneğin 6585 sayılı Perakende Ticaretin Düzenlenmesi Hakkında Kanun'un 5. maddesinin yedinci fikrasına göre "Büyükşehirlerde, alışveriş merkezlerine yapı ruhsatı, yapı kullanma izin belgesi ve işyeri açma ve çalışma ruhsatı vermeye büyükşehir belediyeleri yetkilidir." Buna karşın, büyükşehir belediyeleri alışveriş merkezlerindeki ilan ve reklam faaliyetlerine ilişkin vergiyi toplamaya yetkili değildir. Alışveriş merkezleri 5216 sayılı Büyükşehir Belediyesi Kanunu'nun 23. maddesinin birinci fikrasının (e) bendinde sayılan yerlerden olmadığı için, buralarda İlan ve Reklam Vergisi'nin genel yetkili olan ilçe belediyeleri tarafindan tahsili gerekir.

Büyükşehir belediyelerinin İlan ve Reklam Vergisi alabileceği yerlerin bu derece kısıtlı olması dikkate değerdir. Zira 5216 sayılı Büyükşehir Belediyesi Kanunu'nun 7. maddesi büyükşehir belediyelerine kendi görev ve hizmetlerin gerektirdiği proje, yapım, bakım ve onarım işleriyle ilgili her ölçekteki imar planlarını, parselasyon planlarını ve her türlü imar uygulamasını yapmak ve ruhsatlandırmak; büyükşehir belediyesi tarafından yapılan veya işletilen alanlardaki işyerlerine büyükşehir belediyesinin sorumluluğunda bulunan alanlarda işletilecek yerlere, ulaşım ve toplu taşıma hizmetlerine, toplu taşıma araçları ve taksilerin durak yerlerine, araç park yerlerine, birinci sınıf gayrisıhhî müesseselere, yolcu ve yük terminallerine, kapalı ve açık otoparklara, sosyal donatılar ve tesislere, toptanc1 hallerini ve mezbahalara, bölge parkları, hayvanat bahçeleri, hayvan barınakları, kütüphane, müze, spor, dinlence, eğlence ve benzeri yerlere ilişkin yapmak, ruhsatlandırmak ve işletmek gibi görev ve yetkileri vermiştir. Fakat büyükşehir belediyeleri buralardaki İlan ve Reklam Vergisi'ni tahsil etme yetkisini haiz değildir,

sokak, park, spor ve kültürel tesislerin büyükșehir belediyesi ile büyükșehir kapsamındaki diğer belediyeler arasında dağılımına ilişkin esaslar büyükşehir belediye meclisi tarafindan belirlenir" hükmü anılan Kanun'un 7. maddesinin birinci fikrasinın (g) bendinde belirtilen alanlar olan mahalleleri ilçe merkezine bağlayan yollar, meydan, bulvar, cadde ve ana yolların kendiliğinden büyükşehir belediyesi yetkisinde olmadığını göstermektedir. $\mathrm{Bu}$ yerlerin büyükşehir belediyesi yetkisinde olması için büyükșehir belediye meclisinin bu yönde bir karar alması zorunludur.

22 'Cephe' ibaresi imar parselleri ve binalar için uzunluk, derinlik, yükseklik, ön ve arkada olma gibi boyutlarıyla 3194 sayılı İmar Kanunu'na dayalı olarak 3.7.2017 tarihli ve 30113 sayılı Resmî Gazete'de yayımlanan Planlı Alanlar İmar Yönetmeliği’nde düzenlenmiştir.

${ }^{23}$ Danıştay 9. Dairesi'nin 22.5.2007 tarihli ve E.2006/2122, K.2007/2029 sayılı kararı (Danıştay Dergisi, 2008: 243).

24 Danıştay 9. Dairesi'nin 29.5.2007 tarihli ve E.2006/994, K.2007/2103 sayılı kararı (Danıştay Dergisi, 2008: 249). 
verginin ilçe belediyesi tarafından tahsil edilmesi gerekmektedir.

Ayrıca diğer mevzuatla düzenlenen organize sanayi bölgeleri $^{25}$ ve serbest bölgeler ${ }^{26}$, ilçe mülki sınırları üzerindeki hava sahası (balon, zeplin, uçak vb. ile yapılan reklamlar için), ilçe mülki sınırları içindeki kıyılar ve bu kıyılardan itibaren Devlet karasuları (deniz üstü ve altı araçlarda yapılan reklamlar için), ticari ve hususi $\operatorname{araçlar}^{27}$ üzerindeki reklamlardan doğacak İlan ve Reklam Vergisi genel yetkili olan ilçe belediyelerince tahsil edilmelidir.

2014 yılından itibaren 6360 sayılı Kanun sonucunda hizmet alanı genişleyen büyükşehir belediyelerinin ve büyükşehir ilçe belediyelerinin harcama ihtiyaçları artmakla birlikte bunların öz gelir kaynaklarını artırıcı bir düzenleme yapılmamıştır (Arıkboğa, 2018: 277). Büyükşehir belediyeleri ile büyükşehir ilçe belediyelerinin mali yapısı ile İlan ve Reklam Vergisi gelirlerinin bütçe içindeki payları dikkate alınarak İlan ve Reklam Vergisi toplama yetkisinin büyükşehir ilçe belediyelerine bırakılması faydalı olacaktır. Tahsilat ve denetim masrafları yüksek olan İlan ve Reklam Vergisi için büyükşehir belediyelerinin ilave çaba göstermesi gereksizdir (Arıkboğa, 2016: 291). Büyükşehir belediyeleri ile büyükşehir ilçe belediyeleri arasında İlan ve Reklam Vergisinin toplanması konusunda görev ve yetki karmaşası olduğu algısı, Çapar ve Demir (2017: 51) tarafından saha araştırması ile tespit edilmiştir. Hâlihazırda ilçe belediyeleri İlan ve Reklam Vergisi toplamak için gerekli idari kapasiteyi (organizasyon, personel, yazılım, donanım vb.) oluşturmuştur. İlçe belediyelerinin büyükşehir belediyesinin yetki alanındaki yerlerde (büyükşehir belediyesinin yapımını ve bakımını üstlendiği yollar ve meydanlarda) bulunan mükelleflerden vergi toplamasının marjinal maliyeti muhtemelen büyükşehir belediyelerinin İlan ve Reklam Vergisi tahsili için yaptığı ortalama maliyetten düşük olacaktır. Başka bir deyişle, büyükşehir sınırları içinde İlan ve Reklam Vergisi'nin ilçe belediyeleri tarafından toplanması maliyet açısından daha verimli olacaktır.

Büyükşehir belediyesi ile büyükşehir ilçe belediyesi arasındaki görev ve yetkilerin sadeleştirilerek bir görev ve yetkinin sadece bir idarenin uhdesine bırakılması ahenk ve eşgüdüm açısından faydalıdır. Bu açıdan İlan ve Reklam Vergisi toplama gibi mikro, mutat ve sınırlı bir konunun ilçe belediyesine bırakılması, büyükşehir belediyesinin de kentin geneline şamil konulara odaklanması gerekir (Alıcı ve Kizılboğa Özaslan, 2017: 264). Finansal olarak da büyükşehir ilçe belediyelerinin 6360 sayılı Kanun sonrasında azalan mali kaynaklarını artırmak için büyükşehir olan illerde İlan ve Reklam Vergisi'ni tahsil yetkisinin ilçe belediyelerine bırakılması düşünülebilir (Çapar ve Demir, 2017: 82). Örneğin, Marmara Belediyeler Birliği (2015: 19)

${ }^{25} 4562$ say1lı Organize Sanayi Bölgeleri Kanunu'nun 21. maddesinde “OSB tüzel kişiliği, bu Kanunun uygulanması ile ilgili işlemlerde her türlü vergi, resim ve harçtan muaftır" hükmü bulunmakla birlikte bu hüküm organize sanayi bölgelerinde bulunan işyerlerinden İlan ve Reklam Vergisi alınmasına engel değildir.

263218 sayılı Serbest Bölgeler Kanunu'nun 6. maddesinde sayılan muafiyetler ve 12. maddesinde sayılan uygulanmayacak kanun hükümleri arasında İlan ve Reklam Vergisi yer almadığı için serbest bölgelerdeki ilan ve reklamlar vergiye tabidir.

${ }^{27}$ 6.8.2011 tarihli ve 28017 sayılı Resmi Gazetede yayımlanarak yürürlüğe konulan Ticari Araçlarda Reklam Bulundurulması Hakkında Yönetmeliğin 5. maddesine göre ticari araçlara reklam uygulanabilmesi için büyükșehir belediyesinden yetki belgesi alınması zorunlu olmasına rağmen, anılan büyükșehirlerde İlan ve Reklam Vergisi toplama yetkisinin ilçe belediyelerine devredilmesi, buna mukabil tahsil edilen vergi tutarının \%25'inin ilçe belediyeleri tarafından büyükşehir belediyelerine verilmesini önermektedir. Aynı öneri 11. Kalkınma Planı Yerel Yönetimler ve Hizmet Kalitesi Özel İhtisas Komisyonu Raporu'nda (ÖİK, 2019: 136) da yer almış ve iki yıl içinde gerçekleştirilmesi planlanmıştır.

Konunun bir diğer boyutu da ilan ve reklama ilişkin belediyelerce çıkarılan yönetmelikler hakkında Sayıştay görüşü alınmasıdır. 21.2.1967 tarihli ve 832 sayılı (mülga) Sayıştay Kanunu'nun 105. maddesinde "Bakanlıklar ve Sayıştayın denetimine giren diğer idare ve kurumlarca malî konularda düzenlenecek yönetmeliklerle tüzükler ${ }^{28}$, Saylştayın istişari mütalâası alındıktan sonra yürürlüğe konulabilir." hükmü bulunmaktaydı. Bahse konu Kanun'u ilga ve ikame eden 3.12.2010 tarihli ve 6085 sayılı Sayıştay Kanunu'nun 27. maddesinin dördüncü fikrasında yer alan "Genel yönetim kapsamindaki kamu idarelerince mali konularda düzenlenecek yönetmelikler ile yönetmelik niteliğindeki düzenleyici işlemler, Sayıştayın istişari görüşü alınarak yürürlüğe konulur." hükmüyle bu düzenleme korunmuştur. Bunlara paralel biçimde 19.12.2005 tarihli ve 2005/9986 sayılı Bakanlar Kurulu Kararıyla yürürlüğe konulan Mevzuat Hazırlama Usul ve Esasları Hakkında Yönetmeliğin 6. maddesine göre Sayıştay'ın denetimine tabi kamu kurum ve kuruluşlarınca mali konularda düzenlenecek yönetmelik taslakları hakkında Sayıştay Başkanlığı'nın görüşünün alınması zorunludur. Belediyelerin çıkaracağı yönetmelikler için Sayıştay’ın istişari görüşünün alınması yönündeki mevzuatın amir hükmü uzun süredir yürürlükte olmasına rağmen, örneğin en büyük nüfusa sahip 5 büyükşehir belediyesinin (İstanbul, Ankara, İzmir, Bursa ve Antalya) ilan ve reklam konusunu düzenleyen yönetmelikleri incelendiğinde sadece Antalya Büyükşehir Belediyesi'nin Sayıştay görüşü aldığı görülmektedir. ${ }^{29}$ Sayıştay'ın mali konuları düzenleyen yönetmelikler için vereceği görüş yönetmeliğin asli şekil şartlarından olduğu için, Sayıştay incelemesinden geçmemiş ilan ve reklam yönetmeliğinin dava açılması halinde iptali mümkün olabilecektir.

\section{5. İlan ve Reklam Vergisi Gelirlerinin Belediye Gelirleri İçindeki Yeri}

Bir ülkenin vergi sistemi, iktisadi, siyasi ve toplumsal yapının yansıması olarak gelişir. İyi bir vergi sisteminde şu öğelerin bulunması çok önemlidir (Musgrave ve Musgrave, 1989: 216):

1. Elde edilen gelir yeterli olmalıdır.

Yönetmelikte ve dayandığı kanunlarda İlan ve Reklam Vergisi’ne ilişkin bir düzenleme yoktur.

${ }^{28} \mathrm{Bu}$ kanun hükmündeki Sayıştay’ın tüzükler hakkındaki görüş verme yetkisi Anayasa Mahkemesi'nin 16.1.1969 tarihli ve E.1967/19, K. 1969/6 sayılı kararıla (17.4.1970 tarihli ve 13474 sayılı Resmi Gazete'de yayımlanmıştır) iptal edilmiştir.

${ }_{29}$ Bir yönetmelik hakkında Sayıștay görüşü bulunması halinde, yönetmeliğin yürürlük maddesinde 'Sayıştayca incelenmiş olan bu Yönetmelik’ ibaresi bulunur. İstanbul, Ankara, İzmir ve Bursa büyükşehir belediyelerinin kurumsal internet sitesindeki ilan ve reklamları düzenleyen yönetmeliklerinin yürürlük maddesinde mezkûr ibare bulunmadığı için Sayıştay tarafından incelenmediği değerlendirilmiştir. 
2. Vergi yükü adil olarak dağıtılmalıdır.

3. Vergi mükellefinin kim olduğunun yanı sıra gerçekte vergi yükünü kimin üstlendiği dikkate alınmalıdır.

4. Vergi, kişilerin iktisadi kararlarını etkilemeyecek ve etkin çalışacak bir piyasayı bozmayacak şekilde tasarlanmalıdır.

5. Vergi yapısı, mali istikrar politikalarını ve büyüme hedeflerine erişmeyi kolaylaştırmalıdır.

6. Vergi sistemi mükelleflerin anlayabileceği biçimde tasarlanmalıdır, keyfi olmayan ve adil bir şekilde idare edilmelidir.

7. Vergi idaresinin maliyeti ve mükelleflerin vergi mevzuatına riayet için üstlendiği maliyetler mümkün olduğunca az olmalı, ayrıca vergi ihdasını gerektiren diğer hedeflerle uyumlu olmalidir.

İlan ve Reklam Vergisi kişilerin ödeme gücüne göre değil, ilan ve reklamlardan maktu olarak alındığı için gelir dağılımının eşitsizliği ölçüsünde tersine artan oranlı ve bu sebeple adaletsiz bir yapıdadır. Beyanname ile ödendiği için verginin tarh ve tahsil sürecinde mükelleflerin riayet maliyeti vardır ve belediyelerin personel çalıştırması gereklidir. Bu açıdan vergi idaresinin bir maliyeti vardır. Değişen iktisadi şartlardan ötürü fazla bir değişkenlik göstermemesi açısından da istikrarlı bir gelir kaynağıdır (Nacar, 2005: 172175). İlan ve Reklam Vergisi'nden elde edilen gelir belediyeler için küçük bir meblağdır, fakat verginin tahsil maliyeti ile kıyaslandığında verimli bir gelir kalemidir. Vergi yükünü bizzat tabela sahipleri üstlenmektedir fakat bu vergi yükü önemsiz denilebilecek bir tutarda olduğundan kişilerin iktisadi kararlarını etkileyecek bir yekûn tutmamaktadır.

İyi vergi sisteminin genel özelliklerinin yanı sıra mahalli idarelere mahsus olmak üzere yerel vergi sisteminin yerel hizmetlerden faydalanma karşılığında alınması böylece belediyenin kaynak tahsisinin verilen hizmetlerle ilişkisinin kurulmasını temin etmesi (etkinlik), vergi mükellefinin vergiyi doğrudan ödemesi ve vergi yükünü hissetmesi (görünürlük), mahalli müşterek hizmetleri yerel vergilerle finanse etmesi (özerklik), yerel vergi matrahının yerleşik olması (verginin konusu olan iktisadi faaliyetlerin başka yere göç edememesi) ilkeleriyle de desteklenmesi faydalı olur (Nacar, 2005). İlan ve Reklam Vergisi, belediye hizmetleriyle ilişkili olmadığı için faydalanma esasına dayanmamaktadır ve belediyelerin etkin kaynak dağılımına katkı sunmaz. Diğer taraftan mükellefler ödediği vergiyi bilmekte ve vergi yükünü hissetmektedir, böylece bu vergi türü belediyenin toplumsal denetimine hizmet edebilir. Mahalli müşterek hizmetlerin halkın tercihleri doğrultusunda yerel vergilerle finanse edilmesi bağlamında İlan ve Reklam Vergisi'nin yerel vergi düzeninin özerkliği açısından yetersiz olduğu görülmektedir. Türk yerel mali yapılanması, merkezi idareden gelecek transfer gelirlerine önemli derecede bağımlı olduğu ve yerel yönetimlere esneklik tanımadığı için yerel yönetimlerin özerkliğini kısıtlamasına karşın, bölgesel dengesizlikleri azaltmak, makroekonomik amaçlara ulaşmak ve toplumsal refahı artırmak açısından faydalıdır (Nacar, 2005: 172-173).

İlan ve Reklam Vergisi'nin keyfi uygulandığı söylenemese bile bazı mükelleflerden tahsil edilmediği görülmektedir. Vergilendirmede vatandaşların doğrudan erişebildiği belediye başkanlarının genellikle kendilerine siyasi kazanç getirecek faaliyetleri yapmayı tercih etmesinin yerel vergilerin tarh, tahakkuk ve özellikle tahsil sürecini ve oranını etkilemesi beklenebilir, bu açıdan merkezi idarenin vergileme sürecinde daha etkin çalışması mümkündür (Dulupçu vd., 2014: 46). İlaveten genellikle belediyeler verginin getirdiği külfetin kanun gereği olduğunu, vergiyi tahsil etmek zorunda olduklarını ve sorumluluğun merkezi idareye ait olduğunu ifade ederek seçmenleri küstürmemeye gayret etmektedir (Tosuner, 1995: 269). Sayıştay tarafından yayımlanan 2016 ve 2017 yıllarına ait Dış Denetim Genel Değerlendirme Raporlarında bazı belediyelerde İlan ve Reklam Vergisi tahakkuk ve/veya tahsilinin yapılmadığının, 2014 ve 2015 yıllarında da bazı belediyelerin kiraya verdikleri reklam panolarında yapılan reklamlar üzerinden İlan ve Reklam Vergisi almadığının tespit edildiği belirtilmektedir (Sayıştay Başkanlığı 2015, 2016, 2017, 2018).

Grafik 1'de görüldüğü üzere Türkiye'de belediye gelirleri içinde merkezi idare vergi gelirlerinden alınan paylar toplam belediye gelirleri içinde \%60'a yaklaştığı için belediyenin seçilmiş yöneticileri ve karar alıcıları belediye gelirlerinden doğacak seçmen tepkisinden kaçınma şansına sahip olmaktadır. Belediyelerin tahsil ettiği vergilerden elde ettiği gelirler ise toplam belediye gelirleri içinde yaklaşık \%15 düzeyindedir. Bunlar içinde de Emlak Vergisi toplam belediye vergi gelirleri içindeki \%60'lık oranıyla en önemli vergi kalemidir.

Grafik 1. Belediye Gelirleri İçindeki Merkezi İdare Vergi Gelirleri Paylarının ve Belediye Vergi Gelirlerinin Oranı

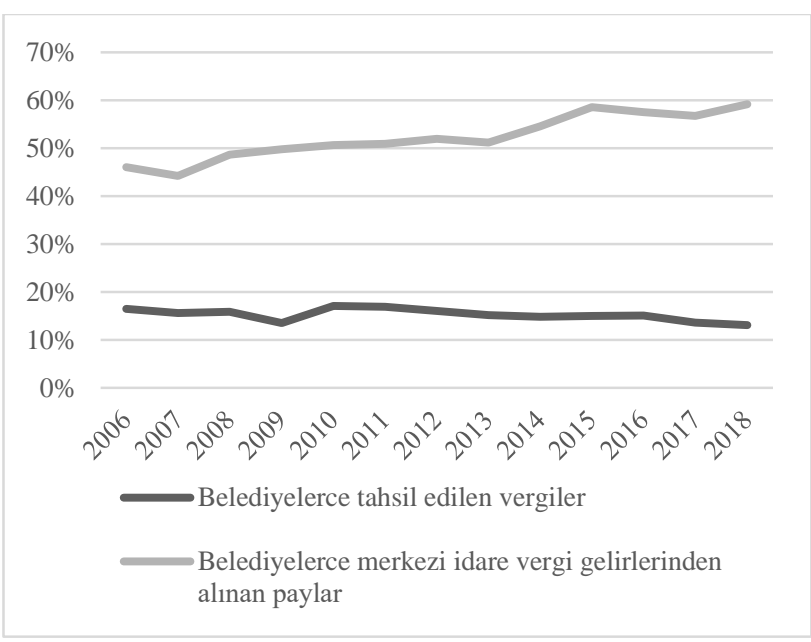

Kaynak: Muhasebat Genel Müdürlüğ̈̈’nün (2019) 'Belediyeler Bütçe İstatistikleri' verilerinden oluşturulmuştur.

Grafik 2'de y1llar itibariyle belediyeler tarafindan tahsil edilen İlan ve Reklam Vergisi tutarları (2018 yılı fiyatlarıyla) sunulmaktadır. Muhasebat Genel Müdürlüğü verilerine göre 2018 yılında ülkede belediyelerin toplam gelirleri yaklaşık 111 milyar TL iken belediyeler tarafindan tahsil edilen İlan ve Reklam Vergisi tutarı 481 milyon TL'dir. İlan ve Reklam Vergisi genel olarak istikrarlı bir gelir kaynağı olmuştur ve dönemsel iktisadi durumlardan ziyade mevzuata bağlı olarak değişim göstermiştir. Ayrıca kurulan yeni işyerleri sonucunda mükellef sayısının artması da vergi tahsilatını olumlu etkilemektedir. 2006 yılında 280 milyon TL (2006 
fiyatlarıyla nominal olarak 105 milyon TL) olan tahsilat tutar1 13 y1l zarfinda \%72 oranında artarak 481 milyon TL'ye ulaşmıştır. Belediyelerden veri toplamadan bu artışın sebebini kesin olarak tespit etmek zordur. Fakat 2013 y1lına kadar vergi tarifesini belirleme yetkisi belediye meclislerinde olduğu için, belediye meclislerinin birbirleriyle tezat olan 'belediye gelirlerini yükseltmek' ve 'vatandaşların tepkisini çekmemek' hedeflerini gözeterek mevcut iktisadi duruma göre tarife tespit ettiği tahmin edilebilir. Zira 2006-2013 döneminde vergi tahsilatında istikrarlı bir artış vardır.

Grafik 2. İlan ve Reklam Vergisi Tahsilatı

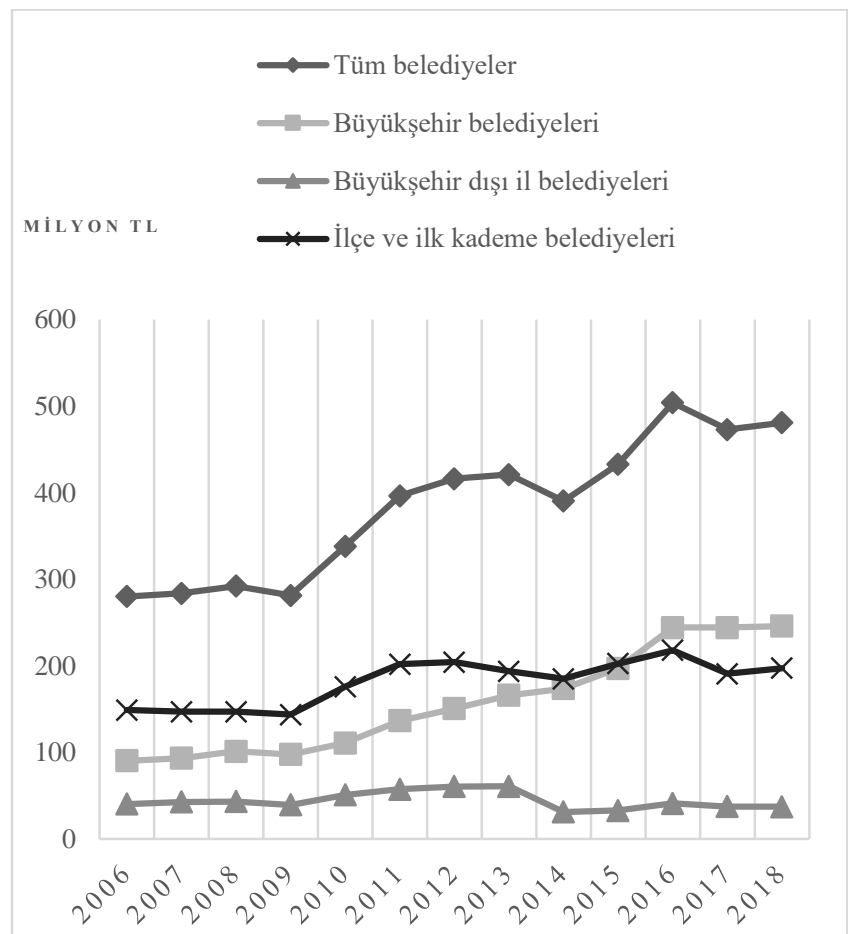

Kaynak: Muhasebat Genel Müdürlüğ̈̈’nün (2019) 'Belediyeler Bütçe İstatistikleri' verilerinden gayri safi yurtiçi hâsıla deflatörü kullanılarak sayıların 2018 yilı cari fiyatlarına yükseltilmesiyle oluşturulmuştur.

2014 yılından sonraki vergi tahsilatı artışının sebebi, yasal dayanağı olmamasına rağmen belediye meclislerinin İlan ve Reklam Vergisi tarifesi belirlemeye devam etmeleri ve/veya belediyelerin tahsilat imkânlarını genişleterek daha önce vergi tahsil etmedikleri mükelleflerden ve yeni mükelleflerden de vergi tahsiline başlaması olabilir.

6360 sayılı Kanun'la 2014 yılından itibaren 14 il daha büyükşehir statüsü kazanmış, il mülki sınırı büyükşehir belediyesi, ilçe mülki sınırı da ilçe belediyesi yetki alanına girmiştir. Fakat belediyelerin yetki alanının genişlemesi İlan ve Reklam Vergisi mükelleflerini artırmamıştır. 6360 sayılı Kanun'un geçici 1. maddesinin onbeşinci fikrasına göre "tüzel kişiliği kaldırılan köylerde, ... 2464 sayıl Belediye Gelirleri Kanunu uyarınca alınmasl gereken vergi, harç ve katılım payları 31/12/2017 tarihine $^{30}$ kadar" alınmayacaktır. Dolayısıyla önceden belediye yetki alanında olmayan yerlerden İlan ve Reklam Vergisi tahsilatı yapılmamıştır. Dahası 6360 sayılı Kanun'un geçici 2. maddesinin birinci

\footnotetext{
${ }^{30} \mathrm{Bu}$ tarih önce 7061 sayılı Kanun'un 105. maddesiyle 31.12.2020 tarihine, sonra 7159 say1lı Kanun'un 6. maddesiyle 31.12.2022 tarihine kadar uzatılmıștır.

31 Fakat ilave mükellef sayısı sadece sabit ilan ve reklamlar için geçerli olacaktır. 2464 sayılı Kanun'da yer alan motorlu taşıtlar üzerindeki ve
}

fikrasıyla büyükșehirler dıșındaki 559 belediyenin tüzel kișiliği kaldırılmış ve bunlar köy statüsüne getirilmiştir. Böylece kapanan 559 belediyenin varsa tahsil ettiği İlan ve Reklam Vergisi 2014 yılından itibaren tahsil edilemez hale gelmiştir.

Tablo 1. İlave Mükellef Kaynaklı Tahsilat Değişimi

\begin{tabular}{|c|c|c|c|c|}
\hline & $\begin{array}{c}\text { İlan ve } \\
\text { Reklam } \\
\text { Vergisi } \\
\text { tahsilatı (bin } \\
\text { TL) }\end{array}$ & $\begin{array}{c}\text { İlave } \\
\text { mükellef } \\
\text { sayısı }\end{array}$ & $\begin{array}{c}\text { Bir önceki } \\
\text { yıla göre } \\
\text { tahsilat } \\
\text { değişimi (bin } \\
\text { TL) }\end{array}$ & $\begin{array}{l}\text { Her bir ilave } \\
\text { mükellef için } \\
\text { ilave tahsilat } \\
\text { (TL) }\end{array}$ \\
\hline 2006 & 280.286 & 88.891 & & \\
\hline 2007 & 283.874 & 85.316 & 3.588 & 42 \\
\hline 2008 & 292.424 & 75.033 & 8.550 & 114 \\
\hline 2009 & 281.490 & 81.929 & -10.934 & -133 \\
\hline 2010 & 338.296 & 87.584 & 56.806 & 649 \\
\hline 2011 & 396.637 & 71.657 & 58.342 & 814 \\
\hline 2012 & 416.476 & 59.241 & 19.838 & 335 \\
\hline 2013 & 421.100 & 59.415 & 4.624 & 78 \\
\hline 2014 & 390.704 & 59.550 & -30.396 & -510 \\
\hline 2015 & 433.348 & 34.077 & 42.644 & 1.251 \\
\hline 2016 & 504.151 & 39.425 & 70.803 & 1.796 \\
\hline 2017 & 473.244 & 45.396 & -30.907 & -681 \\
\hline 2018 & 481.031 & 43.228 & 7.787 & 180 \\
\hline
\end{tabular}

Kaynak: İlan ve Reklam Vergisi tahsilatı sütunu Muhasebat Genel Müdürlüğü'nün (2019) 'Belediyeler Bütçe İstatistikleri' verilerinden gayri safi yurtiçi hâsıla deflatörü kullanılarak sayıların 2018 yılı cari fiyatlarına yükseltilmesiyle oluşturulmuştur. İlave mükellef sütunu, kurulan ve kapanan şirketler ile gerçek kişilerce kurulan işletmelere ilişkin istatistiklerinden İlan ve Reklam Vergisi mükellefi ${ }^{31}$ olacak ilave şirket ve işletmelerin hesaplanmasıyla oluşturulmuştur. 2010-2018 yıllarına ilişkin veriler Türkiye Odalar ve Borsalar Birliği (2019), 2006-2009 yıllarına ilişkin veriler Türkiye İstatistik Kurumu'ndan (2019) alınmıştır.

Tablo 1'de ve grafik 3'te iktisadi hayata yeni katılan işletmelerin İlan ve Reklam Vergisi tahsilatına etkisi olup olmadığına dair veriler sunulmaktadır. Görüldüğü üzere, her bir yeni işletmenin sabit bir reklam tabelası sahibi ve dolayısıyla İlan ve Reklam Vergisi mükellefi olduğu varsayımıyla, mükellef sayısındaki artış tahsilatı doğrudan artırmamaktadır. Hatta bazı yıllarda mükellef sayısı artmakla birlikte tahsilat tutarı azalmaktadır. $\mathrm{Bu}$ durum bazı mükelleflerden vergi tahsil edilemediğini göstermektedir.

geçici mahiyetteki reklamlar, dağıtılan ürünler (katalog, broşür vb.) ve afiş gibi vergiyi doğuran olaylardan kaynaklanan vergi tahsilatı artışı da olabilir. 
Grafik 3. İlave Mükellef Kaynaklı Tahsilat Değişimi

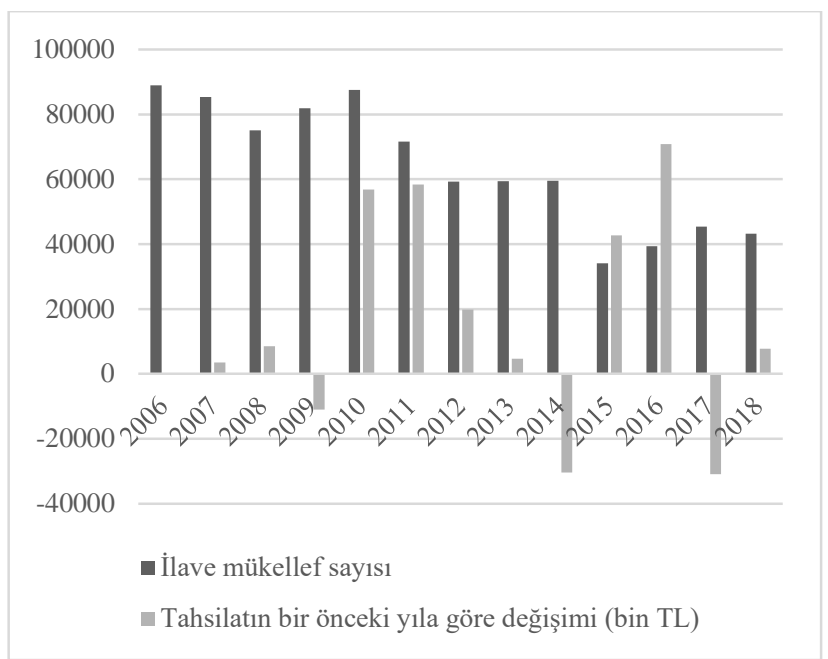

Kaynak: Tablo 1'deki verilerden oluşturulmuştur.

Tablo 2'de İlan ve Reklam Vergisi'nin belediye vergi gelirleri içindeki oranları yer almaktadır. Büyükşehir belediyelerince sadece İlan ve Reklam Vergisi, Eğlence Vergisi ile Yangın Sigortası Vergisi tahsil edildiği için İlan ve Reklam Vergisi'nin büyükșehir belediyesi vergi gelirleri içindeki payı yüksektir. Diğer belediyeler için en verimli vergi olan Emlak Vergisi önemli bir gelir kaynağı olduğu için İlan ve Reklam Vergisi’nin görece ağırlığı azalmaktadır.

Tablo 2. İlan ve Reklam Vergisi'nin Belediye Vergi Gelirleri İçindeki Oranı

\begin{tabular}{ccccc}
\hline & $\begin{array}{c}\text { Tüm } \\
\text { belediyel } \\
\text { er }\end{array}$ & $\begin{array}{c}\text { Büyükşehir } \\
\text { belediyeleri }\end{array}$ & $\begin{array}{c}\text { Büyükşehir } \\
\text { diș il } \\
\text { belediyeleri }\end{array}$ & $\begin{array}{c}\text { İlçe ve ilk } \\
\text { kademe } \\
\text { belediyeleri }\end{array}$ \\
\hline 2006 & $3,13 \%$ & $17,90 \%$ & $10,67 \%$ & $1,95 \%$ \\
2007 & $3,36 \%$ & $17,86 \%$ & $11,21 \%$ & $2,07 \%$ \\
2008 & $3,46 \%$ & $18,79 \%$ & $9,05 \%$ & $2,10 \%$ \\
2009 & $4,04 \%$ & $20,46 \%$ & $11,12 \%$ & $2,52 \%$ \\
2010 & $3,24 \%$ & $21,80 \%$ & $8,50 \%$ & $1,99 \%$ \\
2011 & $3,48 \%$ & $24,79 \%$ & $9,88 \%$ & $2,05 \%$ \\
2012 & $3,69 \%$ & $37,64 \%$ & $8,89 \%$ & $2,08 \%$ \\
2013 & $3,54 \%$ & $35,16 \%$ & $8,42 \%$ & $1,87 \%$ \\
2014 & $3,14 \%$ & $29,01 \%$ & $7,51 \%$ & $1,66 \%$ \\
2015 & $3,19 \%$ & $32,21 \%$ & $7,14 \%$ & $1,66 \%$ \\
2016 & $3,47 \%$ & $34,17 \%$ & $7,73 \%$ & $1,67 \%$ \\
2017 & $3,37 \%$ & $34,86 \%$ & $7,04 \%$ & $1,52 \%$ \\
2018 & $3,32 \%$ & $36,77 \%$ & $7,76 \%$ & $1,51 \%$ \\
\hline
\end{tabular}

Kaynak: Muhasebat Genel Müdürlüğ̈̈’nün (2019) 'Belediyeler Bütçe İstatistikleri' verilerinden oluşturulmuştur.

Tablo 3'te İlan ve Reklam Vergisi'nin belediye toplam gelirleri içindeki oranı mevcuttur. Görüldüğü üzere hiçbir belediye grubunda İlan ve Reklam Vergisi'nin ağırlığ $1 \% 1$ 'e dahi ulaşmamaktadır. Dolayısıyla önemli bir gelir kalemi olmamasına karşın tabela kirliliğini önlemek işlevi gözetilerek İlan ve Reklam Vergisi'nin devam ettirilmesi bir ihtiyaç olarak görülebilir.

Tablo 3. İlan ve Reklam Vergisinin Belediye Toplam Gelirleri İçindeki Oranı

\begin{tabular}{|c|c|c|c|c|}
\hline & $\begin{array}{l}\text { Tüm } \\
\text { belediyel } \\
\text { er }\end{array}$ & $\begin{array}{l}\text { Büyükşehir } \\
\text { belediyeleri }\end{array}$ & $\begin{array}{l}\text { Büyükşsehir } \\
\text { dışı il } \\
\text { belediyeleri }\end{array}$ & $\begin{array}{l}\text { İlçe ve ilk } \\
\text { kademe } \\
\text { belediyeleri }\end{array}$ \\
\hline 2006 & $0,51 \%$ & $0,41 \%$ & $0,74 \%$ & $0,55 \%$ \\
\hline 2007 & $0,52 \%$ & $0,43 \%$ & $0,70 \%$ & $0,55 \%$ \\
\hline 2008 & $0,55 \%$ & $0,50 \%$ & $0,72 \%$ & $0,55 \%$ \\
\hline 2009 & $0,55 \%$ & $0,45 \%$ & $0,71 \%$ & $0,60 \%$ \\
\hline 2010 & $0,55 \%$ & $0,47 \%$ & $0,74 \%$ & $0,58 \%$ \\
\hline 2011 & $0,59 \%$ & $0,53 \%$ & $0,77 \%$ & $0,59 \%$ \\
\hline 2012 & $0,59 \%$ & $0,56 \%$ & $0,75 \%$ & $0,58 \%$ \\
\hline 2013 & $0,54 \%$ & $0,55 \%$ & $0,66 \%$ & $0,50 \%$ \\
\hline 2014 & $0,47 \%$ & $0,43 \%$ & $0,53 \%$ & $0,49 \%$ \\
\hline 2015 & $0,48 \%$ & $0,47 \%$ & $0,49 \%$ & $0,48 \%$ \\
\hline 2016 & $0,52 \%$ & $0,54 \%$ & $0,58 \%$ & $0,49 \%$ \\
\hline 2017 & $0,46 \%$ & $0,50 \%$ & $0,49 \%$ & $0,41 \%$ \\
\hline 2018 & $0,43 \%$ & $0,45 \%$ & $0,46 \%$ & $0,41 \%$ \\
\hline
\end{tabular}

Kaynak: Muhasebat Genel Müdürlüğ̈’nün (2019) 'Belediyeler Bütçe İstatistikleri' verilerinden oluşturulmuştur.

Muhasebat Genel Müdürlüğü tarafından sunulan veriler arasında ilçe ve ilk kademe belediyeleri için toplam olarak sunulan sayıların büyükşehir ilçe belediyelerine ait olan kısmı mevcut değildir. Bu sebeple, büyükşehir belediyeleri ve büyükşsehir ilçe belediyelerinin ne kadar İlan ve Reklam Vergisi'ni tahsil ettiği, makalenin ilerleyen kısmında tartışılacağı üzere İlan ve Reklam Vergisi toplama yetkisinin büyükşehir ilçe belediyelerine bırakılması halinde doğabilecek mali sonucun ne olacağı tahmini yapılamamıştır.

\section{6. İlan ve Reklam Vergisi Tarifesinin Belirlenmesindeki Sorunlar}

Mahalli idarelerin vergilendirme yetkisine sahip olması veya bu yetkinin sınırları konusunda ülkeler arasında önemli farklılıklar mevcuttur (bkz. Çağan, 1980; Kızıler ve Çetinkaya, 2015). Mahalli idarelerin vergilendirme yetkileri yerel nitelikteki vergilerin belirlenmesi ve bu konudaki yasama yetkisinin kullanılması gibi çok geniş olabilir yahut sadece parlamentonun tespit ettiği vergilerin tarh ve tahsiline ilişkin de olabilir. Merkezi idare ile mahalli idareler arasındaki vergilendirme yetkisinin bölüşümü anayasalarda belirlenir. Yerel özelliği daha ağır basan vergilerin mahalli idareler tarafindan belirlenmesi ve tahsil edilmesi 
demokratik devlet ilkesine daha uygun düşecektir (Çağan, 1980: 136).

Cumhuriyetin kurulmasından itibaren belediyeler, bazı vergileri toplama yetkisinin yanında bazı vergilerin tutarını belirleme yetkisini de haiz olmuştur. 1924 yılında yürürlüğe giren 423 sayılı Belediye Vergi ve Resimleri Kanunu, 1930 yılında yürürlüğe giren 1530 sayılı Belediye Kanunu, (423 sayılı Kanunu ikame eden) 1948 yılında yürürlüğe giren 5237 sayılı Belediye Gelirleri Kanunu bu yönde düzenlemeler içermektedir (Öz, 2012: 69-70).

1981 tarihli 2464 sayılı Belediye Gelirleri Kanunu'nda ${ }^{32}$ bazı vergi oranları doğrudan kanunda belirtilmiş, bazı vergi ve harçlar için kanunda belirtilen en az ve en çok sınırları arasında kalmak üzere tarife belirleme yetkisi Bakanlar Kurulu'na verilmiştir. Ayrıca, 2464 sayılı Kanunun 96. maddesinin (B) fikrasında "IIlan ve Reklam Vergisi tarifeleri 2464 sayllı] Kanunda belirtilen en alt ve en üst sinırları aşmamak şartıyla mahallin çeşitli semtleri arasındaki sosyal ve ekonomik farklılıklar gözönünde tutularak belediye meclislerince tespit olunur." denilmek suretiyle belediye meclislerine maktu vergi tutarını belirleme yetkisi verilmiştir. Fakat bu hüküm Anayasa'nın 73. maddesinin üçüncü ve dördüncü fikralarında yer alan "Vergi, resim, harç ve benzeri mali yükümlülükler kanunla konulur, değiştirilir veya kaldırılır. Vergi, resim, harç ve benzeri mali yükümlülüklerin muaflik, istisnalar ve indirimleriyle oranlarına ilişkin hükümlerinde kanunun belirttiği yukarı ve aşağı sınırlar içinde değişiklik yapmak yetkisi Bakanlar Kuruluna verilebilir." hükmüne aykırılık teşkil etmiştir. Zira Anayasa açıkça kanunda belirtilen yukarı ve aşağı sınırlar içinde değişiklik yapmak yetkisini Bakanlar Kurulu'na (2018 yılından itibaren Cumhurbaşkanı'na) verirken 2464 sayılı Kanun bu konuda belediye meclisini yetkilendirmiştir.

1948 yılında yürürlüğe giren 5237 sayılı Belediye Gelirleri Kanununda belediye meclislerinin bazı vergi tutarlarını belirleme yetkisi mevcuttu. 2464 sayılı Kanun, ikame ettiği 5237 sayılı Kanun'daki bu yetkiyi muhafaza etmiştir. Diğer taraftan, 2464 sayılı Kanun'un Anayasa'ya aykırılığı iddiasıyla incelenmesi mümkün olmamıştır çünkü Milli Güvenlik Konseyi yönetimi döneminde çıkarılmıştır. 1982 Anayasası'nın geçici 15. maddesi uyarınca bu dönemde çıkarılan kanunların Anayasa'ya aykırılı̆̆ı iddia edilememiştir. Anayasa'nın geçici 15. maddesinin 2010 yılında yürürlükten kaldırılmasının ardından 2464 sayılı

\footnotetext{
32 29.5.1981 tarihli ve 17354 sayılı Resmi Gazete'de yayımlanmıştır.

33 Danıştay Vergi Dava Daireleri Kurulu'nun itiraz yoluyla başvurusu üzerine Anayasa Mahkemesi'nin 29.12.2011 tarihli ve E. 2010/62, K. 2011/175 sayılı iptal kararı; 19.5.2012 tarihli ve 28297 sayılı Resmi Gazete'de yayımlanmıștır.

${ }^{34}$ Anayasa Mahkemesi'nin 10.4.2013 tarihli ve E. 2012/158, K. 2013/55 sayılı kararı; 18.1.2014 tarihli ve 28886 sayılı Resmi Gazete'de yayımlanmıștır.

35 11.6.2013 tarihli ve 28674 say1l Resmi Gazetede yayımlanan 24.5.2013 tarihli ve 6487 sayılı Bazı Kanunlar ile 375 Sayılı Kanun Hükmünde Kararnamede Değişiklik Yapılması Hakkında Kanun'un 16. maddesiyle 2464 sayılı Kanun'un 96. maddesinin (A) fikrası şu şekilde değiştirilmiştir: "Bakanlar Kurulu, bu Kanunda en az ve en çok miktarlarl gösterilen vergi ve harçların tarifelerini belediye gruplart itibarlyla tayin ve tespit eder., 6487 sayılı Kanun'un 16. maddesi, Resmi Gazete'deki yayım tarihinden önceki bir tarih (ve Anayasa Mahkemesi'nin iptal kararının yürürlük tarihi) olan 19.5.2013 tarihinden itibaren yürürlüğe girmiştir. Yasama organının kanun konusundaki gecikmesi belediyeler ve mükellefler açısından ilave iş yükü doğurmuştur. Ayrıca kişiler üzerine mali bir yük getiren kanunun
}

Kanun'un Anayasa'ya aykırılık iddiasıyla incelenmesi mümkün olmuştur (Öz, 2012: 80-81).

Anayasa Mahkemesi 2012 y1lındaki bir kararıyla ${ }^{33} 2464$ sayılı Belediye Gelirleri Kanunu'nun İlan ve Reklam Vergisi de dâhil olmak üzere belediye meclislerine bazı vergi ve harçların maktu tarifelerini düzenleme yetkisi veren 96 . maddesinin (B) fikrasını Anayasa'ya aykırı bularak iptal etmiştir. Mahkeme vergilendirmede kuralın vergilerin kanunla konulması, kaldırılması ve değiştirilmesi olduğunu belirterek, parlamentonun vergilerin yukarı ve aşağı sınırları belirleme yetkisine sahip olduğunu ve bu sınırlar içinde değişiklik yapma yetkisinin ise kanunun öngörmesi koşuluyla münhasıran Bakanlar Kurulu'na (2018 y1lından itibaren Cumhurbaşkanı'na) verilebileceğini kaydetmiştir. Bakanlar Kurulu'na (2018 y1lından itibaren Cumhurbaşkanı'na) verilen bu yetki istisnai bir yetkidir ve belediye meclislerine vergi tarifesini belirleme yetkisi veren hüküm Anayasa'nın 73. maddesine aykırıdır. Anayasa Mahkemesi yasama organının konuyu düzenlemesine imkân sağlamak için iptal hükmünün, kararın Resmi Gazete'de yayımlanmasından başlayarak bir yıl sonra (19.5.2013 tarihinde) yürürlüğe girmesine karar vermiştir.

Anayasa Mahkemesi 2013 yılındaki başka bir kararında ${ }^{34}$ ise 2464 say1lı Belediye Gelirleri Kanunu'nun 60. maddesi uyarınca tahsil edilen 'Tatil Günlerinde Çalışma Ruhsatı Harcı' tutarının kanunda belirtilen sınırlar dâhilinde belediye meclislerince tespit edilebileceği yönündeki hükmü Anayasa'ya aykırı bulmamıştır. Mahkeme bu kararını yerel yönetimlerin özerkliğini düzenleyen Anayasa'nın 127. maddesi ile Avrupa Yerel Yönetimler Özerklik Şartı'na dayandırmıştır. Fakat Anayasa Mahkemesi'nin bu kararı Anayasa'nın 73. maddesine uygun değildir (Yakar ve Gündüz, 2014: 138).

2013 yılında yapılan bir kanun ${ }^{35}$ değişikliği ile belediye meclisleri yerine Bakanlar Kurulu'nun (2018 y1lından itibaren Cumhurbaşkanı'nın) İlan ve Reklam Vergisi tarifelerini belirlemesi düzenlenmiştir. 2014 yılında yapılan bir kanun $^{36}$ değişikliği ile İlan ve Reklam Vergisi tarifelerinin hazırlanması sürecine belediye meclisleri de katılmak istenmiştir. Buna göre Anayasa Mahkemesince iptal edilen hükme benzer biçimde, mahallin çeşitli semtleri arasındaki sosyal ve ekonomik farkl1lıklar göz önünde tutularak ilgili belediye meclisleri kanunun öngördüğü en az ve en çok tutarlar arasında İlan ve Reklam Vergisi tarifesini kabul ederek merkezi idareye öneri sunacaktır. Bakanlar

geçmişe etkili olarak yürürlüğe konulması, hukuk devleti ilkesine ve dolayısıyla Anayasa'nın 2. maddesine aykırılık teşkil etmektedir.

${ }^{36}$ 1.3.2014 tarihli ve 28928 sayll Resmi Gazete'de yayımlanan 26.2.2014 tarihli ve 6527 sayılı Bazı Kanunlarda Değişiklik Yapılması Hakkında Kanun'un 5. maddesiyle 2464 sayılı Kanun'un 96. maddesinin (A) fikrasına şu paragraf ilave edilmiştir: “Ancak, bu Kanunun 15 inci maddesinde... yer alan [İlan ve Reklam Vergisi] maktu vergi ve harç tarifeleri, Kanunda belirtilen en alt ve en üst sınırları așmamak şartıyla mahallin çeșitli semtleri arasindaki sosyal ve ekonomik farklılıklar göz önünde tutularak ilgili belediye meclislerinin önerisi, İçişleri Bakanlığının görüşü ve Maliye Bakanlı̆̆ının teklifi üzerine Bakanlar Kurulunca [Cumhurbaşkanınca] tespit edilir. Tespit edilen bu tutarlar, her takvim yll başından geçerli olmak üzere bir önceki yıla iliskin olarak Vergi Usul Kanunu hükümlerine göre belirlenen yeniden değerleme oranında artırılır. Bu şekilde hesaplanan miktar ve tutarların, virgülden sonraki iki hanesi dikkate alınarak uygulanır. Şu kadar ki, bu miktar ve tutarlar ilgili tarifeler için belirlenen en çok tutarı aşamaz. Bu uygulamaya ilişkin usul ve esasları belirlemeye Maliye Bakanlığl yetkilidir." 
Kurulu (2018 yılından itibaren Cumhurbaşkanı) da bu önerileri kabul edebilecektir.

2014 yılında ayrıca Bakanlar Kurulu (2018 yılından itibaren Cumhurbaşkanı) tarafından tespit edilen tutarların her yıl yeniden değerleme oranı kadar artırılması da hüküm altına alınmıştır. Bu düzenleme belediyelerin ve merkezi idarenin iş yükünü azaltması bakımından uygundur. Aynı zamanda vergi tarifelerinin mahallin sosyal ve ekonomik şartlarında esaslı değişiklikler olması halinde güncellenmek üzere belediyeler tarafından yeni öneriler getirilmesi yönünde bir esneklik ihdas etmektedir. Öte yandan güncellenen tarifeler 2464 sayılı Kanun'da belirlenen azami tutarları geçemeyeceği için belirli dönemlerde kanun değişikliği yapılması gerekecektir.

2014 yılında yapılan kanun ${ }^{37}$ değişikliğinde ilaveten bir geçici madde ihdas edilerek Bakanlar Kurulu'nun (2018 yılından itibaren Cumhurbaşkanı'nın) tarifeleri tespitine kadar 2013 yılında uygulanmak üzere belediye meclislerince belirlenmiş olan İlan ve Reklam Vergisi tarifelerinin uygulanmaya devam edeceği düzenlenmiştir. $\mathrm{Bu}$ hüküm yürürlükte olmakla birlikte, vergilerin kanuni olmasını düzenleyen ve vergilerin muaflık, istisna ve indirimleriyle oranlarına ilişkin hükümlerinde kanunun belirttiği yukarı ve aşağı sınırlar içinde değişiklik yapmak konusunda sadece Cumhurbaşkanı'na istisnai olarak yetki veren Anayasa'nın 73. maddesine aykırıdır. İtiraz yoluyla Anayasa Mahkemesi tarafından incelenmesi halinde iptali mümkün olabilecektir.

Belediyelerin önerileri üzerine İlan ve Reklam Vergisi tarifelerini belirlemek için bir Bakanlar Kurulu karar ${ }^{38}$ veya Cumhurbaşkanı kararı yayımlanmamıştır. Dolayısıyla 2464 sayılı Kanun'un geçici 7. maddesi uyarınca belediye meclislerinin 2013 yılında uygulanmak üzere belirlediği İlan ve Reklam Vergisi tarifesi geçerlidir. ${ }^{39}$ Bununla birlikte 2464 sayılı Belediye Gelirleri Kanunu'nun 96. maddesinin (A) fikrasının ikinci paragrafinda Cumhurbaşkanı kararı ile tespit edilen İlan ve Reklam Vergisi tarifesinin her y1l yeniden değerleme oranında artırılması emredilmiş olmasına rağmen anılan Kanun'un geçici 7. maddesinde yeniden değerlemeye ilişkin bir hüküm mevcut değildir. Bu sebeple belediye meclislerinin 2013 yılında tespit ettiği tarife değiştirilmeden ve yeniden değerleme oranı uygulanmadan aynı şekilde icra edilmek zorundadır. $\mathrm{Bu}$ düzenleme Cumhurbaşkanı kararı yayımlanana kadar enflasyon karşısında belediye gelirlerinin erimesine sebep olmakta ve ayrıca mahallin sosyal ve ekonomik şartlarına göre tarifenin güncellenmesine engel olmaktadır.

Avrupa Yerel Yönetimler Özerklik Şartı’yla Türkiye tarafindan belediyelerin yetkilerine ilişskin kabul edilen

\footnotetext{
${ }^{37} 6527$ sayılı Kanun'un 6. maddesiyle 2464 sayılı Kanun'a geçici 7. madde eklenmiştir. Madde metni şu şekildedir: "2013 yılında uygulanmak üzere belediye meclislerince belirlenmiș olan; bu Kanunun 15 inci maddesinde ... yer alan [İlan ve Reklam Vergisi] maktu vergi ve harç tarifeleri, Kanunun 96 ncr maddesinin (A) fikrasinin ikinci paragrafi gereğince Bakanlar Kurulunca [Cumhurbaşkanınca] tespit edilecek karar yürürlüğe girinceye kadar uygulanmaya devam edilir. "'

${ }^{38}$ 18.2.2014 tarihli ve 28917 sayılı Resmi Gazete'de yayımlanan 10.2.2014 tarihli ve 2014/5896 say1lı Bakanlar Kurulu'nun '2464 Say1lı Belediye Gelirleri Kanununda Yer Alan Bazı Maktu Vergi ve Harç Tarifelerinin Belediye Grupları İtibarıyla Tespitine İlişkin Kararın Yürürlüğe Konulmas Hakkında Karar'ı yayımlanmıştır fakat daha sonra yürürlüğe giren 2464 sayılı Kanun'un geçici 7. maddesiyle anılan 2014/5896 sayılı Bakanlar Kurulu Kararı zımnen yürürlükten kaldırılmıştır.

${ }^{39}$ Cumhurbaşkanı kararı yayımlanıncaya kadar İlan ve Reklam Vergisi maktu tarifeleri olarak belediye meclislerince 2013 yılı için belirlenen
}

hükümler ${ }^{40}$ konunun bir diğer boyutunu oluşturmaktadır (Öz, 2012: 81-83; Yakar ve Gündüz, 2014: 138). Türkiye'nin çekince koymadığ1 hükümlerinden birisi olan Şart'ın 9. maddesinin üçüncü fikrasına göre "Yerel makamların mali kaynaklarının en azından bir bölümü oranlarını kendilerinin kanunun koyduğu sinırlar dâhilinde belirleyebilecekleri yerel vergi ve harçlardan sağlanacaktır." Belediye meclisinin İlan ve Reklam Vergisi tarifesi tespit etme yetkisi Şart hükümleriyle uyumlu iken Anayasa Mahkemesi tarafından iptal edilmiştir. Dolayısıyla Şart ile Anayasa arasinda ihtilaf mevcuttur.

Türkiye'de gerek Belediye Kanunu'nda gerekse Büyükşehir Belediyesi Kanunu'nda belediyelerin mali özerkliğe sahip olduğu yer almakla birlikte, belediyelerin Anayasa'nın 127. maddesinde belirtilen görevleriyle orantılı gelir kaynaklarını sağlamak için vergi tarifesi belirleme yetkisi yoktur. Literatürde belediyelere yerel vergi tarifelerini tespit etme yetkisinin verilmesinin gerektiği (örneğin Çağan, 1980: 136; Korlu ve Çetinkaya, 2015: 109-110; Kızıler ve Çetinkaya, 2015: 162; Şahin İpek, 2018: 15) ve bunun için bir Anayasa değişikliği yapılması konusunda pek çok tavsiyede bulunulmuştur (örneğin Tosuner, 1995: 268; Tavşanc1, 2004: 12; Kaplan, 2012: 204; Yakar ve Gündüz, 2014: 138; Dulupçu vd., 2014: 52; Marmara Belediyeler Birliği, 2015: 12; Arıkboğa, 2015: 17; Bozdoğan ve Çataloluk, 2017: 442). Belediyelerin etkin kılınması için mali yerelleşmenin de güçlendirilmesi gerekmektedir; bu çerçevede yerel vergilere ilişkin oran koyma yetkisi belediyelere devredilebilir (Tavşanc1, 2004: 12). Kaplan'a (2012: 204) göre, mahalli idarelere kanunla belirlenen alt ve üst sınırlar içinde yerel vergi, resim, harç ve benzeri mali yükümlülüklerin indirim, istisna, muafiyet ve oranlarına ilişkin düzenleme yapma yetkisi verilmesi bir zorunluluk haline gelmiştir. Çünkü yerel vergilere konu edilecek unsurlar ile ilgili mahalli idareler merkezi idareye kıyasla önemli bir bilgi üstünlüğüne sahiptirler. Fakat bu yöndeki bir düzenleme sadece Anayasa değişikliği ile yapılabilir (Kaplan, 2012). Fransa'da 2003 yılında yapılan bir anayasa değişikliğiyle mahalli idarelerin mali kaynakları anayasal güvenceye kavuşturulmuş, mahalli idarelere bazı vergilerin matrah ve oranlarını tespit etme yetkisinin kanunla verilebileceği düzenlenmiştir (Gözler, 2018: 189). Benzer bir anayasa değişikliğinin yapılması Türk belediyelerinin mali özerkliğini geliştirmek için de düşünülebilir.

\section{Sonuç}

Bu çalışmada, İlan ve Reklam Vergisi'ne ilişkin kanundaki tarifelerin ve vergiyi doğuran olayların güncellenmesi gerektiği belirtilmiş, belediyelere yapılacak bir anayasa

tutarların uygulanacağı Belediye Gelirleri Kanunu Genel Tebliği (Seri No: 45) ile de düzenlenmiştir.

40 Türkiye tarafından 8.5.1991 tarihli ve 3723 sayılı Kanunla onaylanmas uygun bulunan ve Bakanlar Kurulu'nun 6.8.1992 tarihli ve 92/3398 sayılı Kararıyla onaylanan Avrupa Yerel Yönetimler Özerklik Şartı çekince konulan hükümler hariç olmak üzere milli mevzuatın bir parçası olmuştur. Diğer taraftan Anayasa'nın 90. maddesinin beșinci fikrasında “Usulüne göre yürürlüğe konulmuş Milletlerarası andlaşmalar kanun hükmündedir. Bunlar hakkında Anayasaya aykırllı iddiası ile Anayasa Mahkemesine başvurulamaz. Usulüne göre yürürlüğe konulmuş temel hak ve özgürlüklere ilişkin milletlerarası andlaşmalarla kanunların aynı konuda farklı hükümler içermesi nedeniyle çıkabilecek uyuşmazlıklarda milletlerarası andlaşma hükümleri esas alınır." hükmü bulunmasına karşın, Şart temel hak ve özgürlüklere ilişkin olmadığı için belediyelerin Şart'tan kaynaklı bir vergi tarifesi belirleme yetkisi yoktur. 
değişikliğiyle tarife belirleme yetkisi verilmesi ve büyükşehirlerde bu vergiyi toplama yetkisinin tamamen ilçe belediyelerine bırakılması önerilmiştir.

İlan ve Reklam Vergisi tabela ebatlarına dayalı olarak hesaplandığı için, vergiden kaçınmak isteyen mükelleflerin daha küçük tabelaları tercih etmesi sebebiyle, tabela yoğunluğunu azaltıcı bir etkisi vardır. Diğer taraftan bu verginin yabancı dildeki tabelaları sınırlayarak ve caydırıcı tarife uygulayarak Türkçe'yi koruma işlevi de bulunmaktaydı fakat bu işlev 1981 y1lından sonra kaldırılmıştır.

1981 yılından beri İlan ve Reklam Vergisi’ni doğuran olaylar güncellenmemiş, sadece bir defa 2004 y1lında vergi tarifeleri değiştirilmiştir. $\mathrm{Bu}$ durum vergi gelirlerinin ciddi şekilde artmasını engellemiş, ayrıca led ekran, lazer, internet reklamları gibi yeni mecralar üzerindeki vergilemeyi zorlaştırmış veya engellemiştir. Tüm belediye gelirleri içindeki oranı \%o5 civarında olan İlan ve Reklam Vergisi önemli bir gelir kalemi değildir. 2018 yılında ülkede belediyelerin toplam geliri yaklaşık 111 milyar TL iken belediyeler tarafindan tahsil edilen İlan ve Reklam Vergisi tutarı 481 milyon TL olmuştur. Fakat 2006 yılından itibaren yayınlanan verilere göre bu gelir kalemi iktisadi dalgalanmalardan olumsuz etkilenmemektedir ve istikrarlı bir artış seyri vardır. Ayrıca İlan ve Reklam Vergisi kişilerin doğrudan belediyelere ödediği ve vergi yükünü hissettiği yerel bir vergi türüdür.

Belediye meclislerinin kanundaki sınırlar içinde İlan ve Reklam Vergisi'nin tarifesini belirleme yetkisi 2012 yılındaki Anayasa Mahkemesi kararıyla iptal edilmiştir. Bu karar belediye meclisinin yerel ve iktisadi şartlara göre tarife belirleme esnekliğini ortadan kaldırmıștır. Aynı zamanda Türkiye'nin taraf olduğu Avrupa Yerel Yönetimler Özerklik Şartı'nda belediyelere tanınan yetkileri de kısıtlamaktadır. Literatürde çokça ifade edildiği üzere, Anayasa'da yapılacak bir değişiklikle İlan ve Reklam Vergisi de dahil olmak üzere, bazı yerel vergilerin indirim, istisna, muafiyet ve oranlarının kanunda belirlenen alt ve üst sinırlar dâhilinde belediye meclislerince belirlenmesine imkân tanınması yerinde olacaktır.

Büyükşehirlerde İlan ve Reklam Vergisi'ni toplamaya genel yetkili belediye ilçe belediyesidir. Büyükşehir belediyeleri ise sadece kanunda sayılan belirli yerlerde bu vergiyi tahsil edebilir. Fakat bu durum pratikte büyükşehir belediyesi ile ilçe belediyesi arasındaki sorunlara yol açmaktadır. Hem bu sorunları ortadan kaldırmak hem de verginin tahsilini daha verimli kılmak adına, büyükşehirlerde İlan ve Reklam Vergisi toplama yetkisi ilçe belediyelerine bırakılmalıdır.

\section{Kaynakça}

Alıcı, O. V. \& R. Kızılboğa Özaslan (2017). İki Kademeli Büyükşehir Yönetim Sisteminin Yarg1 Kararları Kapsamında İncelenmesi. İçinde: M. Güler \& A. M. Turan (Ed.). Belediyelerin Geleceği ve Yeni Yaklaşımlar 2. Cilt (s. 255-267). İstanbul: Marmara Belediyeler Birliği Kültür Yayınları.

Arıkboğa, Ü. (2015). Türkiye'de Yerel Vergi Yönetimi. Maliye Dergisi, (168), 1-19.

Arıkboğa, Ü. (2016). Türkiye'de Belediyelerin Gelir Yapısı: Sorunlar ve Çözüm Önerileri. Mustafa Kemal
Üniversitesi Sosyal Bilimler Enstitüsü Dergisi, 13 (33), 276-297.

Arıkboğa, Ü. (2018). Metropoliten Yönetimlerde Hizmet Sorumluluklarının Paylaşımı ve Finansmanı. TESAM Akademi Dergisi, Yerel Yönetimler Özel Say1s1, 251-282. http://dx.doi.org/ 10.30626/tesamakademi.419254 (Erişim: 18.7.2019).

Barnett, A. H. \& B. Yandle (2005). Regulation by Taxation. İçinde: J. G. Backhaus \& R. E. Wagner (Ed.), Handbook of Public Finance, Springer: Boston, MA, 217-236.

Bayer, Ç. (2019). İlan ve Reklam Vergisi ve Vakıf Üniversitelerinin Bu Vergi Karşısındaki Hukukî Durumu. Necmettin Erbakan Üniversitesi Hukuk Fakültesi Dergisi, 2 (1), 47-67.

Bozdoğan, D. \& C. Çataloluk (2017). Belediyelerin Vergilendirme Yetkisinin Kanunilik İlkesi Açısından İncelenmesi. Ordu Üniversitesi Sosyal Bilimler Araştırmaları Dergisi, 7 (3), 433-444.

Coşkun Karadağ, N. (2019). İnternet Ortamında Verilen Reklam Hizmetlerinin Vergilendirilmesi. Vergi Raporu, (236), 74-89.

Çağan, N. (1980). Demokratik Sosyal Hukuk Devletinde Vergilendirme. Ankara Üniversitesi Hukuk Fakültesi Dergisi, 37 (1), 129-151.

Çapar, S. \& R. Demir (2017). Türkiye'de Büyükşehir Yapılanması ve 6360 Sayılı Kanuna Uygulayıcıların Bakışı. Türk Idare Dergisi, (484), 39-88.

Çetin, M. \& E. Özkan (2018). Türkiye'de Vergi-Tüketim İlişkisi: Alkol ve Tütün Ürünlerine Yönelik Bir Saha Araştırması. Balıkesir Üniversitesi Sosyal Bilimler Enstitüsü Dergisi, 21 (40), 271-287.

Danıştay Dergisi (2008). Yıl: 38, Sayı: 117.

Doğrusöz, B. (1982). İlan ve Reklam Vergisi. Vergi Dünyası, (14), http://www.vergidunyasi.com.tr/Makaleler/231 (Erişim: 18.7.2019).

Dulupçu, M. A., G. Özkul, H. Ünlü \& M. Sayın (2014). Yerel Yönetimlerin Vergilendirme Yetkisine İlişkin Değerlendirmeler. Süleyman Demirel Üniversitesi Sosyal Bilimler Enstitüsü Dergisi, 2014/2 (20), 27 54.

Gelir İdaresi Başkanlığı (2019a). https://www.gib.gov.tr/fileadmin/mevzuatek/gerek celer/2464_sayili_kanun.pdf (Erişim: 1.7.2019) Belediye Gelirleri Kanunu Genel Gerekçe, Kanun Tasarısı ve Komisyon Raporları. Milli Güvenlik Konseyi Sira Sayıs1: 152.

Gelir İdaresi Başkanlığı (2019b). https:/www.gib.gov.tr/fileadmin/mevzuatek/gerek celer/2464_sayili_kanun.pdf (Erişim: 1.7.2019) Belediye Gelirleri Kanunu.

Gerçek, A. (2005). Türk Vergi Hukukunda Vergi Sorumlusu, Sorumluluk Halleri ve Türlerinin İncelenmesi. 
Ankara Üniversitesi Hukuk Fakültesi Dergisi, 54 (3), 157-193.

Göker, C. (2011). Yönlendirici Vergilendirme. Marmara Üniversitesi Hukuk Fakültesi Hukuk Araştırmaları Dergisi, 17 (3-4), 11-30.

Gözler, K. (2018). Mahallî İdareler Hukuku. Bursa: Ekin.

Gündüzöz, İ. (2016). Büyükşehir Belediyeleri ile İlçe Belediyeleri Arasındaki Uyuşmazlıklar Üstüne Güncel Tartışmalar. İdarecinin Sesi Dergisi, (169), 60-65.

Hayrullahoğlu, B. (2015). Türkiye'de Tütün Mamulleri ve Alkollü İçkilerde Özel Tüketim Vergisinin Başarısı. Journal of Life Economics, 2 (2), 89-112.

Kaplan, R. (2012). Yerel Yönetimlerin Vergiler Konusundaki Düzenleme Yetkilerinin Anayasa Mahkemesinin İptal Kararı Çerçevesinde Değerlendirilmesi. Vergi Dünyası Dergisi, (374), 196-205.

Kızıler, N. \& Ö. Çetinkaya (2015). Seçilmiş Ülkeler Kapsamında Türkiye'deki Belediyelerin Merkeze Bağımlılıklarının Analizi. Marmara Üniversitesi Siyasal Bilimler Dergisi, 3 (1), 135-165.

Korlu, R. K. \& Ö. Çetinkaya (2015). Türkiye'deki Belediyelerin Mali Özerkliğinin Öz Gelirler Bağlamında Analizi ve Değerlendirilmesi. Siyaset, Ekonomi ve Yönetim Araştırmaları Dergisi, 3 (4), 95-111.

Marmara Belediyeler Birliği (2015). Belediyelerin Mali Sorunlart ve Çözüm Önerileri Çalıştay Raporu, İstanbul.

Muhasebat Genel Müdürlüğü (2019). https://muhasebat.hmb.gov.tr/mahalli-idarelerbutce-istatistikleri (Erişim: 1.7.2019) Belediyeler Bütçe İstatistikleri.

Musgrave, R. A. \& P. B. Musgrave (1989). Public Finance in Theory and Practice. 5th ed., New York: McGraw-Hill.

Nacar, B. (2005). Yerel Vergi Düzeni: Kuramsal Temelleri ve Türkiye Uygulaması Üzerine Bir Değerlendirme. İstanbul Üniversitesi İktisat Fakültesi Maliye Araştırma Merkezi Konferansları Dergisi, (47), 157-178.

Ortaç, F. R. \& D. Akçay (2015). Internet and Advertisement Taxation. İçinde: S. Tuna \& D. Akçay (Ed.) Approaches on New Media: Proceedings of 1st International New Media Conference, May 21, 2015, Istanbul, Turkey. Istanbul: Gelisim University Press.

ÖİK (2019). On Birinci Kalkınma Planı (2019-2023) Yerel Yönetimler ve Hizmet Kalitesi Özel Íhtisas Komisyonu Raporu, Cumhurbaşkanlığı Strateji ve Bütçe Başkanlığı.

Öz, N. S. (2012). Anayasa Mahkemesinin Belediye Meclislerinin Vergilendirme Yetkisiyle İlgili Kararına İlişkin Bir Değerlendirme. Ankara
Üniversitesi Siyasal Bilgiler Fakültesi Dergisi, 67 (4), 63-88.

Pigou, A. C. (1920). Economics of Welfare. London: Macmillan.

Sayıştay Başkanlığı (2015). 2014 Yılı Dış Denetim Genel Değerlendirme Raporu. https://www.sayistay.gov.tr/tr/?p=2\&CategoryId=9 7 (Erişim: 1.7.2019).

Sayıştay Başkanlığı (2016). 2015 Y1lı Dış Denetim Genel Değerlendirme Raporu. https://www.sayistay.gov.tr/tr/?p=2\&CategoryId=9 7 (Erişim: 1.7.2019).

Sayıştay Başkanlığı (2017). 2016 Y1lı Dış Denetim Genel Değerlendirme Raporu. https://www.sayistay.gov.tr/tr/?p=2\&CategoryId $=9$ 7 (Erişim: 1.7.2019).

Sayıştay Başkanlığı (2018). 2017 Yılı Dış Denetim Genel Değerlendirme Raporu. https://www.sayistay.gov.tr/tr/?p=2\&CategoryId=9 7 (Erişim: 1.7.2019).

Şahin İpek, E. A. (2018). Türkiye'de Belediye Gelirlerinin Değerlendirilmesi. Afyon Kocatepe Üniversitesi İktisadi ve İdari Bilimler Fakültesi Dergisi, 20 (2), $1-19$.

Şener, M. (1998). Türkiye'de Belediyelerin Finansman Sorunları ve Çözüm Önerileri. Çukurova Üniversitesi Sosyal Bilimler Enstitüsü Dergisi, 5 (5), 7-24.

Tavşanc1, A. (2004). Türkiye'de Yerel İdarelerin Vergilendirme Yetkisi ve 1982 Anayasası. Trakya Üniversitesi Sosyal Bilimler Dergisi, 4 (1), 1-14.

TBMM

(2019).

https://www.tbmm.gov.tr/tutanaklar/KANUNLAR

KARARLAR/kanuntbmmc002/kanuntbmmc002/ kanuntbmmc00200423.pdf (Erişim: 1.7.2019) 423 say1lı Belediye Vergi ve Resimleri Kanunu.

Tosuner, M. (1995). Mahalli İdarelerde Vergilendirme Yetkisi. Dokuz Eylül Üniversitesi İktisadi ve İdari Bilimler Fakültesi Dergisi, 10 (2), 259-272.

Türkiye İstatistik Kurumu (2019). http://www.tuik.gov.tr/OncekiHBArama.do (Erişim: 25.7.2019) Haber Bültenleri: Kurulan ve Kapanan Şirketler.

Türkiye Odalar ve Borsalar Birliği (2019). https://www.tobb.org.tr/BilgiErisimMudurlugu/Sa yfalar/KurulanKapananSirketistatistikleri.php (Erişim: 25.7.2019) Kurulan/Kapanan Şirket İstatistikleri.

Yakar, S. \& İ. O. Gündüz (2014). Türkiye'de Belediyelerin Vergilendirme Yetkisi: 'Var' mı 'Yok' mu İşte Bütün Mesele Bu. Sayıştay Dergisi, (92), 117-141.

Yılmaz, G. (2018). Vergi, Resim, Harç Kavramlarının Tarihsel Devinimi: Kavram Kargaşası Bağlamında 'Resmin' Günümüzdeki Varlık Sorunu. Marmara Üniversitesi İktisadi ve İdari Bilimler Dergisi, 40 (2), 370-393. 